\title{
New insights into the anticancer activity of carnosol: p53 reactivation in the U87MG human glioblastoma cell line.
}

Chiara Giacomellia , Letizia Natali ${ }^{a}$, Maria Letizia Trincavelli ${ }^{\star a, b}$, Simona Daniele ${ }^{a, c}$, Alessandra Bertolia,b, Guido Flaminia,b, Alessandra Bracaa, ${ }^{a, b}$ Claudia Martinia,b.

a Dipartimento di Farmacia, Università di Pisa, Via Bonanno Pisano 6, 56126 Pisa, Italy

b Centro Interdipartimentale di Ricerca "Nutraceutica e Alimentazione per la Salute", Univ. of Pisa, via del Borghetto 80, 56124 Pisa, Italy.

c Department of Pharmacological and Biomolecular Sciences, University of Milan, Italy.

Corresponding authors: Maria Letizia Trincavelli Phone: +39-050-2219523; Fax: +39050-2219609; e-mail: maria.trincavelli@unipi.it. 


\begin{abstract}
Glioblastoma Multiforme (GBM) is an aggressive brain tumour with high resistance to radio- and chemotherapy. As such, increasing attention has focused on developing new therapeutic strategies to improve treatment responses. Recently, attention has been shifted to natural compounds that are able to halt tumour development. Among them, carnosol (CAR), a phenolic diterpene present in rosemary, has become a promising molecule that is able to prevent certain types of solid cancer. However, no data are available on the effects of CAR in GBM. Here, CAR activity decreased the proliferation of different human glioblastoma cell lines, particularly cells that express wild type p53. The p53 pathway is involved in the control of apoptosis and is often impaired in GBM. Notably, CAR, through the dissociation of p53 from its endogenous inhibitor MDM2, was able to increase the intracellular p53 levels in GBM cells. Accordingly, functional reactivation of p53 was demonstrated by the stimulation of p53 target genes' transcription, the induction of apoptosis and cell cycle blockade. Most importantly, CAR produced synergistic effects with Temozolomide (TMZ) and reduced the restoration of the tumour cells' proliferation after drug removal. Thus, for the first time, these data highlighted the potential use of diterpenes in the sensitization of GBM cells to chemotherapy through a direct re-activation of p53 pathway. Furthermore, progress has been made in delineating the biochemical mechanisms underlying the pro-apoptotic effects of this molecule.
\end{abstract}

Keywords: Diterpene; carnosol; Glioblastoma multiforme; p53; Temozolomide. 
Abbreviations: GBM, Glioblastoma multiforme; TMZ, Temozolomide; CAR, carnosol; MDM2, Mouse double minute 2; $\mathrm{CHX}$, Cycloheximide. 


\section{Introduction}

Phytochemicals are defined as the non-nutritive components in plants and are able to influence human health in different ways. Recently, the identification, characterization and development of natural chemotherapeutic molecules with anti-cancer properties has become a major area of cancer research (Johnson and Mukhtar, 2007; Khuda-Bukhsh, 2014; Syed, 2007). The anti-cancer activity of a Rosmarinus officinalis extract has been widely reported in the literature (Fortes, 2003; Huang 1994; Ngo, 2011; Singletary, 1996). Among the different components of rosemary, the diterpene carnosol (CAR) has become one of the major bioactive molecules.

CAR was first isolated in 1942 from Salvia carnosa and possesses a wide range of biological activities, namely anti-microbial (Weckesser, 2007), neuroprotective (Kim, 2006), anti-oxidant (Pérez-Fons, 2010), anti-inflammatory (Altinier, 2007; Johanson, 2011; Poeckel, 2008) and anti-cancer properties (Dörrie, 2001; Huang, 2005; Johanson, 2011; Lo, 2002; Vergara, 2014; Visanji, 2006). Regarding its anti-cancer properties, CAR has been shown to have significant cytotoxic effects in several human cancer cell lines and animal models (Johanson, 2011): HT-1080 human fibrosarcoma cells (López-Jiménez, 2013), MCF-7 human breast cancer cells (Johnson, 2010), PC3 human prostate cancer cells (Johnson, 2008), B-lineage leukaemia cells (Dörrie, 2001) and very recently in human colon cancer cells (Park, 2014). The anti-proliferative effects elicited by CAR have been demonstrated to be preferentially directed towards cancer cells in both in vivo and in vitro models (Johanson, 2011). However, to date, no data have been reported on the effects of this diterpene on central nervous system cancers, particularly Glioblastoma multiforme (GBM).

GBM is one of the most aggressive and deadly forms of primary brain tumours in adults. GBM treatment usually consists of surgical resection, followed by radiotherapy combined with the alkylating agent temozolomide (TMZ) (Sathornsumetee, 2007). Aberrations in different intracellular signalling pathways are involved in the pathogenesis of glioma and cause the escape from cell death that represents an important hallmark of cancers (Mitsutoshi, 2001). In this respect, apoptosis inducers have been emerging as promising drugs in a large number of tumours (Green and Walczak, 2013). Among the different intracellular pathways, the deregulation of the oncosuppressor protein p53 has been widely described, and the reactivation of its endogenous function represents an important tool in GBM treatment (England, 2013; Khoo, 2014; Sato, 2011; Villalonga-Planells, 2011). 
The tumour suppression protein p53 is a transcription factor that regulates cell fate after different stresses, and its activation leads to a cell cycle blockade and an increase in apoptosis (Kruiswijk, 2015). Accordingly, in vivo studies support the idea of pharmacologically restoring p53 functionality in cancer treatment (Xue, 2007; Junttila, 2010; Feldser, 2010)

CAR is able to interfere with several intracellular pathways that are deregulated in inflammation and cancer (Johanson, 2011). Among the different targets of CAR, Park et al. (2014) reported that this natural compound has the ability to increase the intracellular expression level of the $\mathrm{p} 53$ protein.

In the present study, for the first time, the anti-proliferative activity of CAR was investigated in GBM cells and one of its underlying mechanisms of action was explored in depth. CAR was able to decrease the viability of different GBM cell lines; notably, this effect was more evident in cells expressing wild-type p53. Therefore, the p53 pathway was investigated in depth as one of the possible mechanisms of action of CAR. The results demonstrated that CAR had the ability to reactivate p53 pathway, inducing cell cycle arrest and apoptosis. Further examinations of the signalling pathways indicated that CARinduced cell death was partially linked to the direct dissociation of p53 from its physiological inhibitor mouse double minute 2 (MDM2). More interestingly, CAR was able to synergize with a traditional anticancer drug (TMZ). Taken together, these findings could highlight the mechanisms underlying the anticancer effects of CAR on human GBM cells. Furthermore, CAR could represent the starting point for the development of more effective chemotherapeutic agents against highly aggressive brain tumours that act as direct apoptosis inducers and chemosensitisers in combination with standard chemotherapeutic agents.

\section{Experimental}

\subsection{Material}

The human glioblastoma U87MG, T98G and U343MG cell lines were obtained from the National Institute for Cancer Research of Genoa (Italy), American Type Culture Collection (USA) and Cell Lines Service GmbH (Germany), respectively. Each cell line was monitored for DNA profiling. Human Mesenchymal stem cells (MSCs) and cultured media MSCGM were purchased from Lonza srl (Milan, Italy). All other reagents were obtained from standard commercial sources and were of the highest commercially available grade. 


\subsection{Cell lines.}

The U87MG and T98G cells were cultured in RPMI medium and Minimum essential medium Eagle, respectively, supplemented with 10\% FBS, $2 \mathrm{mM} \mathrm{L}$-glutamine, $100 \mathrm{U} / \mathrm{mL}$ penicillin, $100 \mathrm{mg} / \mathrm{mL}$ streptomycin and $1 \%$ non-essential amino acids at $37^{\circ} \mathrm{C}$ in $5 \% \mathrm{CO}_{2}$. U343MG cells were cultured in Minimum essential medium Eagle with $2 \mathrm{mM} \mathrm{L-glutamine}$ and Earle's BSS adjusted to contain $1.5 \mathrm{~g} / \mathrm{L}$ sodium bicarbonate and supplemented with $10 \%$ FBS, $100 \mathrm{U} / \mathrm{mL}$ penicillin, $100 \mathrm{mg} / \mathrm{mL}$ streptomycin, $1 \%$ non-essential amino acids and $1.0 \mathrm{mM}$ sodium pyruvate at $37^{\circ} \mathrm{C}$ in $5 \% \mathrm{CO}_{2}$.

Human MSCs were cultured in normal growth medium (MSCGM, Lonza), plated (5 $\mathrm{x}$ $10^{3}$ cells $\left./ \mathrm{cm}^{2}\right)$ in $75-\mathrm{cm}^{2}$ flasks and incubated at $37{ }^{\circ} \mathrm{C}$ in $5 \% \mathrm{CO}^{2}$ and $95 \%$ air. The medium was changed to remove non adherent cells every 3 to 4 days, and the cells were used at passages 0 to 3 .

\subsection{Cell viability assays of GBM cells and MSC.}

The human GBM cells or MSCs were seeded at a density of $1.5 \times 10^{3}$ cells/well or $3 \times 10^{3}$ cells/well respectively. After $24 \mathrm{~h}$, the cells were treated with fresh growth medium containing different concentrations of CAR (Sigma Aldrich, Cat. C9617) (100 nM-100 $\mu \mathrm{M})$. Following the treatment period, cell proliferation was determined using the MTS assay (CellTiter 96® AQueous One Solution Cell Proliferation Assay kit; Promega) according to manufacturer's instruction. The absorbance of formazan at $490 \mathrm{~nm}$ was measured in a colorimetric assay with an automated plate reader (Victor Wallac 2, Perkin Elmer). For wash-out experiments, U87MG cells were treated with CAR $(100 \mathrm{nM}-60 \mu \mathrm{M})$ or Temozolomide $(100 \mu \mathrm{M}-250 \mu \mathrm{M})$ alone or in combination for $72 \mathrm{~h}$. At the end of treatments, medium-containing drugs was replaced by fresh medium, and cells were allowed to growth for additional $72 \mathrm{~h}$. At the end, cell proliferation was measured using MTS assay as described above. Data were expressed as the percentage of untreated cells proliferation. Sigmoid dose-response curve was generated, from which the $\mathrm{IC}_{50}$ values were derived.

\section{3 siRNA mediated inhibition of p53 expression}

U87MG cells were transfected with a siRNA specifically designed for the silencing of the human p53 (sc-29435 Santa Cruz Biotecnology). The siRNAs have been transfected with siRNA transfection reagent (sc-29528 Santa Cruz Biotecnology) to a final concentration of $50 \mathrm{nM}$, following the manufacturer's protocol. In parallel to each silencing experiment, an ineffective sequence of RNA has been used as negative control (sc-37007 Santa Cruz 
Biotechnology). The efficacy of silencing was verified by real time-RT-PCR. Transfected cells were used $48 \mathrm{~h}$ or $72 \mathrm{~h}$ after siRNA transfection.

\subsection{RNA extraction and Real Time PCR analysis in U87MG cells.}

U87MG cells were treated with DMSO (control) or CAR $(10 \mu \mathrm{M}-20 \mu \mathrm{M})$ for $8 \mathrm{~h}$ or $24 \mathrm{~h}$. At the end of treatments, cells were collected, and total RNA was extracted using Rneasy ${ }^{\circledR}$ Mini Kit (Qiagen, Hilden, Germany) according to manufacturer's instructions. cDNA synthesis was performed with 500 ng of RNA using i-Script cDNA synthesis kit (BioRad, Hercules, USA) following manufacturer's instructions. Real-time RT-PCR reactions consisted of $25 \mu \mathrm{L}$ Fluocycle ${ }^{\circledR}$ II SYBR® (Euroclone, Milan, Italy), $1.5 \mu \mathrm{L}$ of both $10 \mu \mathrm{M}$ forward and reverse primers, $3 \mu \mathrm{L} \mathrm{cDNA}$, and $19 \mu \mathrm{L}$ of $\mathrm{H}_{2} \mathrm{O}$. All reactions were performed for 40 cycles using the following temperature profiles: $98{ }^{\circ} \mathrm{C}$ for 30 seconds (initial denaturation); $\mathrm{T}^{\circ} \mathrm{C}$ (Table 1) for 30 seconds (annealing); and $72{ }^{\circ} \mathrm{C}$ for 3 seconds (extension). Primer used were previously described (Da Pozzo, 2014) and listed in Table 1. $\beta$-actin was used as the housekeeping gene. The mRNA levels for each sample were normalized against $\beta$-actin mRNA levels, and relative expression was calculated by using $\mathrm{Ct}$ value. PCR specificity was determined by both the melting curve analysis and gel electrophoresis.

\section{Table 1. Near here}

\subsection{Western blotting analysis of p53 protein expression.}

The Western blot analysis for the evaluation of p53 protein levels was performed as previously described (Daniele, 2014). In brief, U87MG cells were treated with DMSO (control) or with different CAR concentrations for $8 \mathrm{~h}$ or $24 \mathrm{~h}$, and then lysed for $60 \mathrm{~min}$ at 4 ${ }^{\circ} \mathrm{C}$ by the addition of $200 \mu \mathrm{l}$ RIPA buffer. Equal amounts of the cell extracts (50 $\mu \mathrm{g}$ of proteins) were diluted in Laemmli solution, resolved by SDS-PAGE (7.5\%), transferred to PVDF membranes and probed overnight at $4{ }^{\circ} \mathrm{C}$ with primary antibody anti-p53 (diluted 1:200; FL-393; Santa Cruz Biotechnology) or $\beta$-actin (diluted 1:1000; MAB1501, Merck KGaA, Darmstadt, Germany). The primary antibody was detected using anti-rabbit IgG light chains conjugated to peroxidase (diluted 1:10000; 12-348; Millipore). The peroxidase was detected using a chemioluminescent substrate (ECL, Perkin Elmer). Densitometric analysis of immunoreactive bands was performed using Image $\mathrm{J}$ Software. Western blot analysis was also performed using lysates from CAR treated and untreated GBM cells in the absence or presence of the protein synthesis inhibitor Cycloheximide ( $\mathrm{CHX}, 50 \mu \mathrm{M})$. 


\subsection{Dissociation studies of native MDM2/p53 complex.}

In brief, U87MG cell were suspended in lysis buffer $(20 \mathrm{mM}$ Tris $\mathrm{HCl}, 137 \mathrm{mM} \mathrm{NaCl}$, $10 \%$ glycerol, $1 \%$ NONIDET 40, 2 mM EDTA, pH 8 ) containing $1 \%$ of the Protease inhibitor Cocktail (Sigma Aldrich, Milan, Italy). Cell lysates $(20 \mu \mathrm{g}$ in a final volume of $100 \mu \mathrm{l})$ were pre-incubated with DMSO (control) or different CAR concentration for 10 minutes at room temperature, and then transferred for $60 \mathrm{~min}$ to wells pre-coated with a mouse full-length anti-MDM2 antibody (sc-965, Santa Cruz Biotechnology, 1:50 in 0.05\% Poly-L-Ornithine, overnight at room temperature). After washes, each well was incubated for $15 \mathrm{~min}$ with $1 \%$ $\mathrm{BSA}$, to block nonspecific sites, and then for $1.5 \mathrm{~h}$ at room temperature with a rabbit primary anti-p53 antibody (sc-6243, Santa Cruz Biotechnology, 1:250 in 5\% milk). Then, wells were washed and incubated for $1 \mathrm{~h}$ with an anti-rabbit IgG HRP-conjugate antibody (1:3000 in 5\% milk), and washed again. The TMB substrate kit (Thermo Fisher Scientific) allowed a colorimetric quantification of the MDM2/p53 complex. Blanks were obtained processing cell lysates in the absence of the primary anti-p53 antibody. Absorbance's values at $450 \mathrm{~nm}$ were measured and background subtracted.

\subsection{MDM2/p53 co-immunoprecipitation.}

The amount of MDM2/p53 complex in cell was determined using coimmunoprecipitation experiments; U87MG cells were treated with DMSO (control) or CAR $(1 \mu \mathrm{M}-10 \mu \mathrm{M})$ for $8 \mathrm{~h}$. One milligram of cell lysates was pre-cleared with protein ASepharose $\left(1 \mathrm{~h}\right.$ at $\left.4{ }^{\circ} \mathrm{C}\right)$ to precipitate and eliminate IgG. Samples were then centrifuged for $10 \mathrm{~min}$ at $4{ }^{\circ} \mathrm{C}(14,000 \times \mathrm{g})$. The supernatants were incubated with an anti-MDM2 antibody ( $5 \mu \mathrm{g} / \mathrm{sample}$ ) overnight at $4{ }^{\circ} \mathrm{C}$ under constant rotation and then immunoprecipitated with protein A-Sepharose $\left(2 \mathrm{~h}\right.$ at $\left.4{ }^{\circ} \mathrm{C}\right)$. After washing, the immunocomplexes were resuspended in Laemmli solution and boiled for $5 \mathrm{~min}$, resolved by SDS-PAGE (7.5\%), transferred to PVDF membranes and probed overnight at $4{ }^{\circ} \mathrm{C}$ with anti-p53 (diluted 1:200; FL-393; Santa Cruz Biotechnology) or anti-MDM2 (diluted 1:200; C-18; Santa Cruz Biotechnology) as described above.

\subsection{RNA extraction and Real Time PCR analysis in U87MG cells.}

U87MG cells were treated with DMSO (control) or CAR $(10 \mu \mathrm{M}-20 \mu \mathrm{M})$ for $8 \mathrm{~h}$ or $24 \mathrm{~h}$. At the end of treatments, cells were collected, and total RNA was extracted using Rneasy® Mini Kit (Qiagen, Hilden, Germany) according to manufacturer's instructions. cDNA synthesis was performed with 500 ng of RNA using i-Script cDNA synthesis kit (BioRad, 
Hercules, USA) following manufacturer's instructions. Real-time RT-PCR reactions consisted of $25 \mu \mathrm{L}$ Fluocycle ${ }^{\circledR}$ II SYBR ${ }^{\circledR}$ (Euroclone, Milan, Italy), $1.5 \mu \mathrm{L}$ of both $10 \mu \mathrm{M}$ forward and reverse primers, $3 \mu \mathrm{L} \mathrm{cDNA}$, and $19 \mu \mathrm{L}$ of $\mathrm{H}_{2} \mathrm{O}$. All reactions were performed for 40 cycles using the following temperature profiles: $98{ }^{\circ} \mathrm{C}$ for 30 seconds (initial denaturation); $\mathrm{T}{ }^{\circ} \mathrm{C}$ (Table 1) for 30 seconds (annealing); and $72{ }^{\circ} \mathrm{C}$ for 3 seconds (extension). Primer used were previously described (Da Pozzo, 2014) and listed in Table 1. $\beta$-actin was used as the housekeeping gene. The mRNA levels for each sample were normalized against $\beta$-actin mRNA levels, and relative expression was calculated by using Ct value. PCR specificity was determined by both the melting curve analysis and gel electrophoresis.

\section{Table 1. Near here}

\subsection{Cell cycle analysis.}

U87MG were treated with DMSO or CAR for 48h. The measurement of the percentage of cells in the different cell phases was performed using the Muse ${ }^{\mathrm{TM}}$ Cell Analyzer (Merck KGaA, Darmstadt, Germany), as described previously (Daniele, 2014).

\subsection{Apoptosis analysis.}

U87MG cells were treated with DMSO (control) or CAR for 48h. At the end of the treatment periods, the percentages of living, apoptotic and dead cells were acquired and analyzed by Muse ${ }^{\mathrm{TM}}$ Cell Analyzer, as previously described (Daniele, 2014). The cells positively stained with Annexin $V$ and 7-Aminoactinomycin $D$ (7-AAD) were evaluated to distinguish the live, early apoptotic and late apoptotic/dead cells.

\subsection{Measurement of cell migration by in vitro scratch assay.}

CAR effects on U87MG cell migration were evaluated with a scratch assay. U87MG were seeded in 96 well plates and grown to $90 \%$ of confluence. Then, the scratch was made through the cell layer using a sterile micropipette tip. After washing with PBS, cells were treated with CAR $(1 \mu \mathrm{M}-20 \mu \mathrm{M})$ in medium with $1 \%$ of $\mathrm{FBS}$. The images of the wounded area were captured immediately after the scratch ( $\left.\mathrm{t}_{0}\right)$ and $16 \mathrm{~h}$ later $\left(\mathrm{t}_{16}\right)$ to monitor cell migration into the wounded area. Photographs were then taken at $4 \times$ magnification on an inverted microscope. The migration abilities were quantified by measuring both the average gap width and the percentage of gap closed. The data were analysed with the Image J software (Version 1.410). 


\subsection{Isobolar analysis.}

A graphical assessment of CAR-TMZ synergy with regard to growth inhibition was performed using isobolographic analysis (Tallarida, 1999). The IC 50 of TMZ was plotted on the abscissa, and the iso-effective dose of CAR was plotted on the ordinate. The theoretical additive effect of the two drugs is represented by the straight line connecting the two points. If the experimentally determined data points and their confidence interval fall on this line, the drug effects are additive (no interaction). If the points lie below this line, there is superadditivity (synergy), and if the points lie above this line, there is subadditivity (antagonism). To determine whether the interaction between the two drugs was synergistic, additive or antagonistic, the theoretical additive $\mathrm{IC}_{50 \text {,add }}$ was estimated from the dose-response curves of each drug administered individually. The interaction index, denoted by $Y$, is an assessment of the degree of synergism or antagonism. The index is defined by the isobolar relationship as follows (Tallarida, 2001,1999): $y=a / A+b / B$ where $A$ and $B$ are the doses of drug $A$ (alone) and $B$ (alone) that give the specified effect, and $(a, b)$ are the combination doses that produce the same effect.

\subsection{Statistical analysis.}

The nonlinear multipurpose curve-fitting program Graph-Pad Prism (GraphPad Software Inc., San Diego, CA) was used for data analysis and graphic presentations. All data are presented as the mean \pm SEM. Statistical analysis was performed by one-way analysis of variance (ANOVA) with Bonferroni's corrected t-test for post-hoc pair-wise comparisons. $P$ $<0.05$ was considered statistically significant.

\section{Results}

\subsection{CAR affected cell proliferation.}

The CAR molecule has been demonstrated to have cytotoxic properties that inhibit the proliferation of several cancer cell lines (Johanson, 2011). Surprisingly, there have been no reports on the effect of the rosemary component on brain tumours. Here, the effects of CAR on the U87MG human glioblastoma cell line were investigated.

CAR treatment $(100 \mathrm{nM}-60 \mu \mathrm{M})$ of the U87MG cells for 24,48 or $72 \mathrm{~h}$ caused a significant decrease in proliferation in a time-dependent manner (Fig. 1A-C). This effect appeared to be dose-dependent at each time point, yielding IC 50 values of $28.9 \pm 0.9 \mu \mathrm{M}$, 
$14.9 \pm 1.0 \mu \mathrm{M}$ and $10.4 \pm 0.5 \mu \mathrm{M}$ after $24 \mathrm{~h}, 48 \mathrm{~h}$ and $72 \mathrm{~h}$ of incubation, respectively (Fig. 1D).

To assess whether the U87MG cells could resume proliferation after drug removal, the cells were treated with different compound concentrations (100 nM-60 $\mu \mathrm{M})$ for $72 \mathrm{~h}$, and then washed out for additional $72 \mathrm{~h}$ in drug-free medium. The U87MG cells' proliferation rate was completely restored when low doses of CAR were added (Fig. 1E). However, the cells partially recovered their growth after $72 \mathrm{~h}$ of wash-out when CAR was used at intermediate doses $(20-30 \mu \mathrm{M})$, although the percentage of proliferating cells remained significantly reduced compared to the control cells. Surprisingly, at high concentrations (40-60 $\mu \mathrm{M})$, CAR completely inhibited the ability of U87MG cells to restore their growth. These results suggest that CAR was able to inhibit cell proliferation, and this effect appeared to be irreversible only at the highest concentrations tested.

Then, the effects of CAR on other glioblastoma cell lines were investigated. The U343MG cells express wild-type p53 and, similar to the U87MG cells, overexpress MDM2 (Ishii, 1999). CAR (100 nM-60 $\mu \mathrm{M})$ treatment led to a significant inhibition of U343MG cell viability after both $48 \mathrm{~h}$ and $72 \mathrm{~h}\left(\mathrm{IC}_{50}=19.0 \pm 1.0 \mu \mathrm{M}\right.$ and $11.7 \pm 1.2 \mu \mathrm{M}$, respectively, Fig. 2A; Fig. S1). The results are comparable with those observed in the U87MG cells (Fig. 1B-C) and are in accord with the reported data on the anti-proliferative effects of CAR in other cell lines that express wild-type p53 (Park, 2014; Tai, 2012).

Conversely, the rosemary metabolite on T98G cells (Wang, 2006), which expressed a mutated p53 isoform, was able to produce a significant right shift of the anti-proliferative dose-response curve respect to those obtained in the other GBM cell lines at both 48 and $72 \mathrm{~h}$ (Fig. 2B). The data support the hypothesis that the reactivation of the p53 pathway may be involved in the CAR-mediated effects.

To confirm this, a viability assay was performed in p53-silenced, CAR-treated U87MG cells (Fig. 2C-E). The efficiency of the siRNA transfection in reducing P53 gene expression was demonstrated by real time RT-PCR (Fig. 2C). The anti-proliferative activity of CAR was then evaluated. After $48 \mathrm{~h}$ of treatment, CAR alone decreased the U87MG cells' proliferation at different rates in the negative control (CTRL -) and the p53-silenced cells $\left(\mathrm{IC}_{50}=14.8 \pm 4.3 \mu \mathrm{M}\right.$, Fig. 2D; Fig. S2). These differences were maintained after $72 \mathrm{~h}$ of treatment $\left(\mathrm{IC}_{50}=12.8 \pm 2.7 \mu \mathrm{M}\right.$, Fig. 2E; Fig. S2). However, p53 knock down was not sufficient to completely inhibit the anti-proliferative action of CAR, thus demonstrating that p53 reactivation is only one of several death mechanisms activated by CAR. 
Finally, the CAR selectivity towards healthy cells was investigated. Considering the tight relationship between glioblastoma cells and the mesenchymal stem cell homing $(\mathrm{Ho}, 2013$; Nakamizo, 2006), the selectivity of CAR was evaluated by measuring human Mesenchymal Stem Cells' (MSCs') viability. The MSCs were treated with CAR (100 nM$100 \mu \mathrm{M}$ ) for $48 \mathrm{~h}$ (Fig. 3A-B) or $72 \mathrm{~h}$ (Fig. 3C-D), and cell proliferation was measured using the MTS assay. CAR was able to induce a slight but significant reduction in MSC proliferation at the highest concentration $(60 \mu \mathrm{M})$. However, the percentages of viable MSCs were significantly higher than those observed in the U87MG cells after both $48 \mathrm{~h}$ (MSC: $74.6 \pm 2.1 \%$ versus U87MG $17.3 \pm 2.7 \%$ ) and $72 \mathrm{~h}$ (MSC: $56.5 \pm 1.1 \%$ versus U87MG $9.8 \pm 1.8 \%$ ) of treatment. These data highlight the presence of a favourable therapeutic window for the use of the diterpene derivative as a chemotherapeutic agent.

\subsection{Effects of CAR on p53 reactivation}

\subsubsection{Intracellular p53 levels}

The effect of CAR on the p53 pathway was investigated in depth in the U87MG cell line. CAR treatment of U87MG cells for 8 and $24 \mathrm{~h}$ caused an increase in the intracellular levels of the p53 protein, as demonstrated by western blot analysis (Fig. 4A) and densitometric quantification of the immunoreactive bands (Fig. 4B). This effect was dose-dependent and was already significant at $10 \mu \mathrm{M}$ CAR after $8 \mathrm{~h}$ of cell treatment $(121.0 \pm 4.3$ percent increase in the p53 levels versus the control, which is in accord with previously reported data (Park, 2014)).

It is well known that different mechanisms could increase the intracellular p53 levels, such as de novo protein synthesis or the dissociation of the MDM2/p53 complex (Costa, 2013; Daniele, 2014; Khoo, 2014; Kruiswijk, 2015). Therefore, a potential increase in the p53 mRNA levels was first analysed by real-time RT-PCR (Fig. 4C). Surprisingly, CAR $(10-20 \mu \mathrm{M})$ treatment for $8 \mathrm{~h}$ did not significantly change the levels of the p53 transcript (Fig. 4C). Because it has been shown that the increases in mRNA levels may not be directly correlated to protein expression (Maier 2009), the intracellular levels of the p53 protein were measured in the presence of the protein synthesis inhibitor, $\mathrm{CHX}$. The U87MG cells were treated with CAR alone or with CAR and CHX for $8 \mathrm{~h}$ (Fig. 4D-E). CHX alone, which affects the synthesis of new proteins, was able to significantly decrease the p53 levels with respect to the control. CAR alone increased the intracellular p53 levels. Notably, CHX only slightly decreased the CAR-mediated up-regulation of p53 (CHX: 
$52.9 \pm 10.6 \% ; 10 \mu \mathrm{M}$ CAR $+\mathrm{CHX}: 142.3 \pm 13.5 \%$ versus the control). The results suggested that CAR did not affect p53 translation.

Therefore, the ability of the rosemary metabolite to modulate the stability of the MDM2/p53 complex was investigated using a direct quantitative sandwich immunoenzymatic ELISA assay (Daniele, 2014). The MDMD2/p53 complex that was presented in the U87MG crude lysates was incubated with different concentrations of CAR ( $1 \mathrm{nM}-50$ $\mu \mathrm{M})$. Then, the amount of remaining complex was measured (Fig. 4F). CAR directly dissociated the MDM2/p53 complex, with a maximum percent of dissociation of $45.1 \pm 4.8 \%$ (versus control set to $100 \%$ ) at $1 \mu \mathrm{M}$ CAR. Accordingly, the data were comparable to the dissociation induced by Nutlin-3 $(38.4 \pm 6.3 \%)$, which was used as a control (Daniele, 2014).

A co-immunoprecipitation assay was performed to confirm the ability of CAR to dissociate the MDM2/p53 complex in whole cells. A significant decrease in p53 was detected in the MDM2 immunoprecipitates after $8 \mathrm{~h}$ of treatment with CAR at the $\mathrm{IC}_{50}$ concentration (Fig. 4G-H).

As expected, the CAR concentrations that were able to induce significant dissociation of the complex differed in the isolated complex $(1 \mu \mathrm{M}$; Fig. $4 \mathrm{~F})$ and the whole cells $(10 \mu \mathrm{M}$; Fig. 4G-H). This is likely due to the ability of CAR to permeate the cell, as well as its interaction with other proteins in the whole cells.

\subsection{2 p53 gene transcription}

Functional reactivation of $\mathrm{p} 53$ has been widely correlated to increases in specific p53related genes (Costa, 2013; Daniele, 2014; Khoo, 2014; Kruiswijk, 2015). Thus, a real-time RT-PCR analysis of the p53-related genes was performed after the U87MG cells were treated with CAR $(10-20 \mu \mathrm{M})$ for 8 or $24 \mathrm{~h}$. CAR was able to significantly increase the mRNA levels of all of the p53 target genes (Fig. 5A-B): p21 (with a maximum increase of $\approx$ 2.4-fold), PUMA (with a maximum increase of $\approx 1.6$-fold), and MDM2 (with a maximum increase of $\approx 3$.4-fold).

Then, the expression of other genes that are correlated to p53 reactivation was investigated. The expression of the pro-apoptotic 'multi-domain' Bcl-2 family member Bax and the anti-apoptotic protein Bcl-2 was assessed by real-time RT-PCR analysis. As expected, CAR treatment of the U87MG cells caused a significant increase in Bax (maximum increase of $\approx 1.6$-fold) and a concomitant decrease in Bcl-2 (maximum 
decrease of $\approx 0.6$-fold) (Fig. 5A-B). The results are in accordance with previously reported data showing that CAR modulates Bcl-2 family proteins in other cell lines (Chun, 2014; Dörrie, 2001; Park, 2014).

\subsection{Apoptosis and cell cycle block}

Challenging U87MG cells with CAR for $48 \mathrm{~h}$ induced significant phosphatidylserine externalization, both in the absence (early apoptosis) and presence of 7-Aminoactinomycin $\mathrm{D}$ (7-AAD) binding to DNA (late apoptosis/death). Apoptosis was significantly induced in cells that were treated with $20 \mu \mathrm{M}$ CAR (Fig. 5C-D), the same concentration that was able to stimulate the expression of the PUMA mRNA (Fig. 5B).

Functional reactivation of p53 in proliferating cells is tightly correlated to the activation of the cyclin-dependent kinase inhibitor p21 and the subsequent cell cycle arrest at both G1 and G2 phases (Concin, 2003; Taylor, 2001). Therefore, a cell cycle cytofluorimetric assay was performed (Fig. 4E). CAR dose-dependently affected the cell cycle, causing a decrease in the DNA content in G1/G0 phase and a concomitant increase in the number of cells in $\mathrm{G} 2 / \mathrm{M}$ and $\mathrm{S}$ phases. These data suggest that CAR caused a cell cycle block in G2 phase (Fig. 4E) in accordance with data previously reported in other cell lines (prostate cancer PC3 cells (Johnson, 2008) and MDAMB-231 cells (Al Dhaheri, 2014)), and it was associated with an up-regulation of the CDK inhibitor p21.

The increase in the transcriptional activity of $p 53$, along with the induction of apoptosis and the block of cell cycle demonstrate the ability of CAR to restore the function of p53 and highlight its role in the balance of pro-apoptotic/anti-apoptotic signals in favour of apoptosis induction and proliferation arrest.

\subsection{U87MG cell migration}

GBM is a highly aggressive tumour due to its invasiveness and chemoresistance (Stupp, 2005). Metastasis is the main cause of mortality in cancer, while the key process of metastasis is the migration and invasion of cancer cells into adjacent tissues (Hoelzinger, 2005).

A wound healing assay was performed to assess the effects of CAR on the migration of U87MG cells. CAR treatment for $16 \mathrm{~h}$ significantly inhibited the cells' migration compared to the untreated control cells, as observed by optical microscopy (Fig. 6A). These effects were dose-dependent, and cell motility was abrogated at the highest concentration (20 $\mu \mathrm{M})$. This effect could be partially due to the ability of CAR to block the cell cycle and 
reduce the U87MG cells' viability. However, CAR caused a significant inhibition in cell migration also at the $1 \mu \mathrm{M}$ concentration, which did not affect cell viability (Fig. 6B-C).

These results highlighted that CAR was not only able to affect GBM cell proliferation but was also able to control the tumour cells' migration that is the basis for cancer invasiveness.

\subsection{CAR synergizes with $T M Z$ to induce U87MG cell death.}

Another main feature of GBM is its poor response to therapy and rapid development of drug-resistance. In this respect, a multi-target or combined therapy has been considered a valid tool to overcome this problem (Zimmermann, 2007). To this end, the effect of a combination of CAR and TMZ was investigated by an isobolographic analysis.

TMZ inhibited cell viability in a dose-dependent manner, with an $\mathrm{IC}_{50}$ value in the micromolar range $(169.1 \pm 14.8 \mu \mathrm{M})$ (Fig. $7 \mathrm{~A})$, which is in accord with previously reported data (Torres, 2011). Based on the calculated $I_{50}$ values for CAR and TMZ alone, the theoretical additive $\mathrm{IC}_{50, \text { add }}$ values for CAR/TMZ were calculated for two fixed ratios (1:3 and 1:25) (Table 2). Then, the dose-response curves of U87MG viability were measured for the same fixed-ratio combinations and the experimental $I_{50, \text { mix }}$ values was calculated (Table 2, Figure 7B). A statistical analysis of the data from the isobolographic analysis revealed slight synergistic interactions between CAR and TMZ for the three examined fixed-ratio combinations (Table 2, Fig. 7B). Indeed, the interaction index values of the combinations are $\leq 1$. However, the synergistic effect was more evident when a ratio of 1:25 (CAR/TMZ) was used.

To assess whether U87MG cells resumed proliferation after TMZ and CAR treatment, the cells were washed out in drug-free medium for additional $72 \mathrm{~h}$ (Fig. 7C). The U87MG cells' proliferation rate was completely restored when TMZ or CAR (at low concentration) were used alone. Conversely, the combined treatment caused a decrease in cell proliferation compared to the single treatment. Notably, the combination of TMZ and the highest CAR concentration $(20 \mu \mathrm{M})$ was able to completely inhibit the ability of the U87MG cells to restore their growth (Fig. 7C).

These results suggest that CAR may have chemosensitizing properties and may be able to synergize with classical chemotherapeutic agents to reduce the cells' ability to resume proliferation after chemotherapy.

\section{Insert Table 2 near here}




\section{Discussion}

In this study, we found that the diterpene CAR exerted an anti-proliferative effect in the U87MG cell line through a mechanism that involves the functional reactivation of $p 53$. In addition, CAR synergized with TMZ to induce irreversible cell death, at least at high concentrations.

The discovery of different phytochemicals has become a tool in anticancer therapy (Khuda-Bukhsh, 2014). Secondary metabolites obtained from different plants extracts have been widely used in the treatment of cancer (Cragg, 2005; Newman, 2007). However, GBM remains a challenging disease to treat, primarily due to its extreme complexity and heterogeneity (Kleihues, 2002). Indeed, several intracellular pathways are de-regulated, highlighting the need for molecules that are able to interfere with different intracellular targets. Here, CAR was demonstrated to inhibit the proliferation of GBM cell lines that present different genetic features.

CAR inhibited the glioblastoma cells' proliferation and this effect was more evident in U87MG cells expressing wild-type p53, in accord with previously reported data (Park, 2014; Tai, 2012). A lower activity was observed in p53-mutated T98G cells, a typical cell model that is used as a negative control for studies analysing the reactivation of p53 function (Villalonga-Planells R, 2011), and in p53-silenced cells. In parallel, previous reports demonstrate that CAR is also effective in cells that lack wild-type p53 (p53-null PC3 cells (Al Dhaheri, 2014) and p53-mutant MDA-MB-231 and R280K cells (Johnson, 2008)), but with a lower activity than that observed in cells expressing the wild-type p53 protein. These data highlighted the involvement of the p53 pathway in the anti-proliferative activity of CAR. However, the contributions of other additional mechanisms cannot be excluded.

U87MG is a GBM cell line that is characterized by a defective p53 pathway. Although these cells express wild-type p53, the functional activity of this oncosuppressor protein is impaired as a consequence of the over-expression of the physiological p53 inhibitor mouse double minute 2 (MDM2) (Costa, 2013; Halatsch, 2006; Kondo, 1995; Kim, 2011).

Notably, CAR was able to increase the intracellular level of $p 53$. These results were not due to de novo synthesis of the protein; furthermore, the inability of $\mathrm{CHX}$, a protein synthesis inhibitor, to counteract the effect of CAR on p53 indicates that the primary effect of CAR was likely to inhibit p53 degradation. In fact, one of the mechanisms underlying 
p53 stabilization is the direct dissociation of the MDM2/p53 complex (Costa, 2013; Daniele, 2014). Several molecules with different chemical structures have been reported to interfere with the MDM2/p53 interaction, mainly due to several conformational adjustments (Uhrinova, 2005, Arkin, 2003) in the p53 and MDM2 interaction

Here, for the first time, CAR was demonstrated to stabilize p53 by directly dissociating the MDM2/p53 complex. The discrepancy between its ability to directly dissociate the complex and its anti-proliferative effect is an issue that has been already reported in the literature for other MDM2/p53 inhibitors. In particular, Nutlin-3 dissociates MDM2/p53 complex in a "cell-free" model with an $\mathrm{IC}_{50}$ value in the nanomolar range. However, the anti-proliferative effect on glioblastoma and other cancers is only exerted at higher concentrations that are at least 10 -fold higher than the $I_{50}$ values for the complex dissociation (Costa, 2013b; Daniele, 2014; Künkele, 2012). In accordance, CAR was able to interfere with the formation of the MDM2/p53 complex, presenting the same profile of Nutlin-3.

p53 activation induced the expression of multiple genes involved in the control of cell death/survival (Khoo, 2014; Kruiswijk, 2015; Costa, 2013; Daniele, 2014), such as p21 (also known as $\mathrm{p} 21^{\mathrm{WAF} 1 / \mathrm{Cip} 1}$ ), which promotes cell cycle arrest; the p53 upregulated modulator of apoptosis (PUMA), a critical mediator of p53-dependent apoptosis; and MDM2, which forms a negative feedback loop with p53 (Wagner, 2005). We demonstrated that CAR induced a significant up-regulation of these p53 gene targets. The induction of MDM2 and PUMA mRNA expression by CAR has been demonstrated for the first time. Conversely, the results for p21 expression are in accord with the increase in this transcript shown in other cell lines (Al Dhaheri, 2014; Chun, 2014).

It has been demonstrated that p53 activation is also correlated with the expression of different Bcl-2 family genes (Hemann and Lowe, 2006), including pro-apoptotic (e.g., Bax, p53, and PUMA) and anti-apoptotic genes (e.g., Bcl-2), in different cells. It is well known that the alteration of the balance between the pro-apoptotic and anti-apoptotic genes is the basis for the modulation of cell death (Fabregat, 2007; Kruiswijk, 2015). CAR was able to modulate the expression of these p53-related genes to regulate cellular apoptosis. These data are in agreement with previous reports demonstrating that the anticancer effect of CAR on leukaemia (Dörrie, 2001), prostate cancer (Johnson, 2008; Lopez-Jimenez, 2013), breast cancer (Al Dhaheri, 2014) and colon cancer (Park, 2014) cell lines was due to the activation of the apoptotic pathway of cell death. Thus, the anti-proliferative effects of CAR 
were exerted by the increase in p53 function and the subsequent blockade of cell cycle progression and the induction of apoptosis.

Accumulating in vitro and in vivo data have shown that natural chemopreventive agents enhance the efficacy of chemotherapy and radiotherapy in various cancers by regulating different intracellular pathways (Khuda-Bukhsh, 2014). CAR is able to induce apoptosis in chemoresistant ovarian cancer cells (Tai, 2012) and radiosensitises melanoma cells after radiotherapy (Alcaraz, 2013). The ability of CAR to sensitize other cancer lines was also demonstrated in glioblastoma cells for the first time.

$T M Z$ is an alkylating agent that is used as a first-line chemotherapeutic agent in glioblastoma. CAR was able to synergize with the anti-proliferative effect of TMZ. In the conventional protocol for the treatment of brain tumours (for example with TMZ), the chemotherapeutic agent is administered after the surgical removal in different cycles, with a latency of several days (Ryu, 2014). In this period, even if the drug is cleared, the effect of the drug on the cancer cells could be important. Therefore, the cells' ability to resume proliferation was measured after the drug was removed from the culture medium to mimic the other chemotherapeutic agents. Surprisingly, higher doses of CAR were able to irreversibly inhibit the U87MG cells' viability after the drugs were removed. One hypothesis that could explain these results is the sustained activation of the p53 pathway. In this experimental condition, the threshold of irreversible TMZ damage could be lower and trigger an irreversible death mechanism. However, additional investigations should be performed to assess this hypothesis and better clarify this issue.

The selectivity of anti-tumour agents on cancer cells versus non-malignant cells is an important issue that must be considered to avoid several side effects. The anti-proliferative effects elicited by CAR were preferentially directed towards cancer cells, as reported in both animal and in vitro models (Johanson, 2011). In particular, Johanson et al. (2011) demonstrated that CAR did not affect the viability of prostate epithelial cells. CAR presented a favourable therapeutic window, indicating that the rosemary derivative could be used as a possible chemotherapeutic agent. No hypotheses have been reported in the literature that explain the selectivity of CAR for tumour cells. However, it was able to interfere with the intracellular pathways that are deregulated in tumour cells (e.g., p53), and the selective modulation of these pathways may be crucial for the selective balance between the survival and death of tumour cells. Nevertheless, few data have been reported regarding the differences in p53 expression or mechanism of cell membrane permeation and intracellular stability of CAR, between the two cell models, thus 
highlightening the need of further experiment to better clarify the different activity of CAR in cancer cells versus non-malignant cells.

Taken together, these data demonstrate the ability of CAR to affect different features of GBM, such as proliferation, invasiveness and resistance to therapy, in combination with selectivity towards the tumour cell.

In conclusion, the discovery of the ability of CAR to modulate the glioblastoma cells' proliferation by reactivating p53 functionality could represent the starting point for the development of more effective drugs that act as apoptosis inducers. Moreover, the synergistic effect of CAR with a standard chemotherapeutic drug highlights the possible use of the rosemary extract in the diet as a co-adjuvant in chemotherapy.

\section{Conflict of interest statement}

None.

\section{Acknowledgements}

This work was financially supported by Fondi di Ateneo University of Pisa, PRA_2015_0083. 


\section{Figure Legends}

Fig. 1. Effects of CAR on U87MG cell viability. The cells were treated with the indicated concentrations of CAR in complete medium for $24 \mathrm{~h}$ (A), $48 \mathrm{~h}$ (B) or $72 \mathrm{~h}$ (C). D) Nonlinear regression of the CAR dose-response curve after $24 \mathrm{~h}, 48 \mathrm{~h}$ or $72 \mathrm{~h}$. E) The U87MG cells were treated with CAR $(100 \mathrm{nM}-60 \mu \mathrm{M})$ for $72 \mathrm{~h}$, and the cells were subsequently washed out in drug-free medium for an additional $72 \mathrm{~h}$. At the end of the treatments, cell proliferation was measured using the MTS assay, as described in the Methods section. The data were expressed as a percentage with respect to the untreated cells (control), which was set to $100 \%$, and they were presented as the mean values \pm SEM of three independent experiments, each performed in triplicate. The significance of the differences was determined by one-way ANOVA, followed by Bonferroni's post hoc test: $P \leq 0.05$, ${ }^{* *} P$ $\leq 0.01,{ }^{* * *} \mathrm{P} \leq 0.001$ vs. the control; \# $\mathrm{P} \leq 0.05$, \#\# $\mathrm{P} \leq 0.001$ vs. the cells treated for $72 \mathrm{~h}$.

Fig. 2. Effects of $C A R$ on the proliferation of different GBM cell lines. The U343MG (A) and T98G (B) cells were treated with different concentrations of CAR for $48 \mathrm{~h}$ or $72 \mathrm{~h}$. At the end of the treatments, cell proliferation was measured using the MTS assay. C) The efficiency of p53 silencing was assessed by evaluating the expression of the p53 mRNA using real time RT-PCR. The data were normalized to the $\beta$-actin levels, expressed as fold changes compared to the control (without siRNA), which was set to 1 , and are presented as the means \pm SEM of at least three different experiments. ${ }^{* * *} P<0.001$ vs the control. The negative control and p53-silenced U87MG cells were treated with the indicated concentrations of CAR in complete medium for $48 \mathrm{~h}$ (D) or $72 \mathrm{~h}(\mathrm{E})$. At the end of the treatments, cell proliferation was measured using the MTS assay, as described in the Methods section. The data were expressed as a percentage with respect to the untreated cells (control), which was set to $100 \%$, and were presented as the mean values \pm SEM of three independent experiments, each performed in triplicate. The significance of the differences was determined by one-way ANOVA, followed by Bonferroni's post hoc test: ${ }^{* *} \mathrm{P} \leq 0.01,{ }^{* * *} \mathrm{P} \leq 0.001$ vs. the control.

Fig. 3. Effect of CAR on MSC proliferation. The MSCs were treated with the indicated concentrations of CAR in complete medium for $48 \mathrm{~h}(\mathbf{A})$ or $72 \mathrm{~h}(\mathbf{C})$. Non-linear regression 
of the CAR dose-response curve after $48 \mathrm{~h}$ (B) or $72 \mathrm{~h}$ (D). At the end of the treatments, cell proliferation was measured using the MTS assay, as described in the Methods section. The data were expressed as a percentage with respect to the untreated cells (control), which was set to $100 \%$, and they were the mean values \pm SEM of three independent experiments, each performed in triplicate. The significance of the differences was determined by one-way ANOVA, followed by Bonferroni's post hoc test: ${ }^{* *} P \leq 0.01$, ${ }^{* * *} \mathrm{P} \leq 0.001$ vs. the control.

Fig. 4. p53 stabilization and CAR-induced MDMD2/p53 dissociation. A, B) The U87MG cells were treated with DMSO (control) or CAR for $8 \mathrm{~h}$ or $24 \mathrm{~h}$ and the levels of the p53 protein were evaluated by western blotting. C) The cells were treated with CAR (10 $\mu \mathrm{M}-20$ $\mu \mathrm{M})$ for $8 \mathrm{~h}$ and a Real Time RT-PCR analysis of the p53 mRNA expression levels was performed. The data were expressed as the fold change compared to the levels of the control, which was set to 1 , and were the mean values \pm SEM of three different experiments. D, E) The cells were treated with DMSO (control) or CAR in the absence or presence of $\mathrm{CHX}(50 \mu \mathrm{M})$ for $8 \mathrm{~h}$. At the end of the incubation, the cells were lysed and a western blot analysis using a p53 antibody was performed. The data are expressed as the percentage of the optical density of the immunoreactive bands compared to the control, which was set to $100 \%$, and are presented as the mean values \pm SEM of three different experiments. F) U87MG cell lysates containing the native MDM2/p53 complex were preincubated with DMSO (control) or different concentrations of CAR. Then, the lysates were captured on wells that had been pre-coated with an MDM2 antibody. The levels of the MDM2/p53 complex were quantified using a specific p53 antibody. The data are expressed as the \% of MDM2/p53 complex versus the control, which was set to $100 \%$, and represent the means \pm SEM of three independent experiments performed in duplicate. G, H) The U87MG cells were incubated with CAR for $8 \mathrm{~h}$, followed by immunoprecipitation using an anti-MDM2 antibody. The MDM2/p53 complex and the relative input proteins were detected by p53 immunoblotting. One representative western blot is presented (G). The bar graph $(\mathbf{H})$ shows the quantitative analysis of the western blot, which was performed using the ImageJ programme. The data are presented as the means \pm SEM of three different experiments. The significance of the differences was determined by oneway ANOVA, followed Bonferroni's post hoc test: ${ }^{*} P \leq 0.05,{ }^{* *} P \leq 0.01,{ }^{* *} P \leq 0.001$ vs. the control; \#\# $\mathrm{P} \leq 0.01$ vs. the $\mathrm{CHX}$ alone group. 
Fig. 5. Functional reactivation of $p 53$ and the effects of CAR on gene transcription, the cell cycle and apoptosis. The U87MG cells were treated with CAR $(10 \mu \mathrm{M}-20 \mu \mathrm{M})$ for $8 \mathrm{~h}(\mathbf{A})$ or $24 \mathrm{~h}$ (B). At the end of the incubation, a Real Time RT-PCR analysis of the p53 target genes (p21, MDM2, PUMA, Bax and Bcl-2) was performed. The data were expressed as the fold change versus the levels of the control, which were set to 1 , and were the mean values \pm SEM of three different experiments. C, D) The U87MG cells were treated with DMSO (control) or CAR $(1 \mu \mathrm{M}-60 \mu \mathrm{M})$ for $48 \mathrm{~h}$. At the end of the treatments, the cells were collected and the amount of phosphatidylserine externalization was evaluated using the Annexin $\mathrm{V}$ staining protocol. The distribution of the live, early and late apoptotic cells were shown (C), as well as the total number of apoptotic cells (D). The data were expressed as the percentage of apoptotic cells versus the total cell number and were presented as the means \pm SEM of three different experiments. E) The U87MG cells were treated with DMSO (control) or CAR $(1 \mu \mathrm{M}-40 \mu \mathrm{M})$ for $48 \mathrm{~h}$ and the cell cycle was analysed. The subpopulations of cells in the different cellular phases were shown. The data were expressed as the percentage of cells in the different phases (G0/G1, G2/M or S) versus the total cell number, and they were the mean values \pm SEM of three different experiments. The significance of the differences was determined by one-way ANOVA, followed by Bonferroni's post hoc test: ${ }^{*} P \leq 0.05,{ }^{* *} P \leq 0.01$, ${ }^{* * *} P \leq 0.001$ vs. the control.

Fig. 6. Effect of CAR on U87MG cell migration. The cells were treated with CAR (1 $\mu \mathrm{M}-20$ $\mu \mathrm{M})$, and the healing of the scratch wounds was evaluated. A) Representative images of the scratch wounds at $0 \mathrm{~h}$ and $16 \mathrm{~h}$. B) The average widths of the gaps of five scratch wounds was initially measured at $0 \mathrm{~h}$ (to) and then measured after $16 \mathrm{~h}\left(\mathrm{t}_{16}\right)$. The data are presented as the means \pm SEM of at least two different experiments performed in triplicate. ${ }^{* *} \mathrm{P}<0.01,{ }^{* *} \mathrm{P}<0.001$ vs. the respective average gaps at to. C) The percentage of gap closure compared to the untreated cells (control). The data are presented as the means \pm SEM of at least two different experiments performed in triplicate. The significance of the differences was determined by one-way ANOVA, followed by Bonferroni's post hoc test: \#\# P $\leq 0.01$, \#\# P $\leq 0.001$ vs. the control.

Fig. 7. The synergistic effect of CAR and TMZ. A) Non-linear regression of the TMZ doseresponse curve after $72 \mathrm{~h}$ of treatment. At the end of the treatments, cell proliferation was measured using the MTS assay. The data were expressed as a percentage with respect to the untreated cells (control), which was set to $100 \%$, and they were the mean values \pm 
SEM of three independent experiments, each performed in triplicate. B) The isobologram shows the interactions between CAR and TMZ in the MTS viability tests performed in the U87MG cells that had been treated for $72 \mathrm{~h}$. The $\mathrm{IC}_{50}$ values for TMZ and CAR are shown on the $\mathrm{X}$ - and $\mathrm{Y}$-axes, respectively. The open points on the additivity line depict the theoretical I $\mathrm{C}_{50, \text { add }}$ values. The solid points depict the experimental IC $\mathrm{C}_{50 \text {,mix }}$ values for total dose, which is expressed as the proportion of CAR and TMZ that produced a $50 \%$ effect. C) The U87MG cells were treated with CAR alone or in combination with the indicated concentration of TMZ for $72 \mathrm{~h}$, and the cells were subsequently washed out for additional $72 \mathrm{~h}$ in drug-free medium. At the end of the treatments, cell proliferation was measured using the MTS assay, as described in the Methods section. The data were expressed as a percentage with respect to the untreated cells (control), which was set to $100 \%$, and they were the mean values \pm SEM of three independent experiments, each performed in triplicate. The significance of the differences was determined by one-way ANOVA, followed by Bonferroni's post hoc test: ${ }^{*} \mathrm{P} \leq 0.05$, ${ }^{* * *} \mathrm{P} \leq 0.001$ vs. the control; ${ }^{\circ} \mathrm{P} \leq 0.05$, ${ }^{\circ 0} \mathrm{P} \leq 0.01,{ }^{\circ 0} \mathrm{P} \leq 0.001$ vs. the respective cells treated for $72 \mathrm{~h} ; \# \mathrm{P} \leq 0.05, \# \mathrm{P} \leq 0.01$, \#\#\# $P \leq 0.001$ vs. the respective TMZ treatment; $\S P \leq 0.05$, $\S \S \S P \leq 0.001$ vs. the respective CAR treatment. 


\section{References}

Al Dhaheri Y, Attoub S, Ramadan G, Arafat K, Bajbouj K, Karuvantevida N, AbuQamar S, Eid A, Iratni R. Carnosol induces ROS-mediated beclin1-independent autophagy and apoptosis in triple negative breast cancer. PLoS One. 2014; 9:e109630.

Alcaraz M, Achel DG, Olivares A, Olmos E, Alcaraz-Saura M, Castillo J. Carnosol, radiation and melanoma: a translational possibility. Clin Transl Oncol. 2013; 15:712-9.

Altinier G, Sosa S, Aquino RP, Mencherini T, Della Loggia R, Tubaro A. Characterization of topical antiinflammatory compounds in Rosmarinus officinalis L. J Agric Food Chem. 2007; 55:1718-23.

Arkin MR, Randal M, DeLano WL, Hyde J, Luong TN, Oslob JD, Raphael DR, Taylor L, Wang J, McDowell RS, Wells JA, Braisted AC. Binding of small molecules to an adaptive protein-protein interface. Proc Natl Acad Sci U S A. 2003; 100:1603-8.

Chun KS, Kundu J, Chae IG, Kundu JK. Carnosol: a phenolic diterpene with cancer chemopreventive potential. J Cancer Prev. 2014; 19:103-10.

Concin N, Stimpfl M, Zeillinger C, Wolff U, Hefler L, Sedlak J, Leodolter S, Zeillinger R. Role of p53 in G2/M cell cycle arrest and apoptosis in response to gamma-irradiation in ovarian carcinoma cell lines. Int J Oncol. 2003; 22:51-7.

Costa B, Bendinelli S, Gabelloni P, Da Pozzo E, Daniele S, Scatena F, Vanacore R, Campiglia P, Bertamino A, Gomez-Monterrey I, Sorriento D, Del Giudice C, laccarino G, Novellino E, Martini C. Human glioblastoma multiforme: p53 reactivation by a novel MDM2 inhibitor. PLoS One. 2013; 8:e72281.

Costa B, Grillone AF, Salvetti A, Rocchiccioli S, lacopetti P, Daniele S, Da Pozzo E, Campiglia P, Novellino E, Martini C, Rossi L. An antibody-free strategy for screening putative HDM2 inhibitors using crude bacterial lysates expressing GST-HDM2 recombinant protein. Drug Test Anal. 2013 Jul; 5:596-601.

Cragg GM, Newman DJ. Plants as a source of anti-cancer agents. J Ethnopharmacol. 2005; 100:72-9.

Da Pozzo E, La Pietra V, Cosimelli B, Da Settimo F, Giacomelli C, Marinelli L, Martini C, Novellino E, Taliani S, Greco G. p53 functional inhibitors behaving like pifithrin- $\beta$ counteract the Alzheimer peptide non- $\beta$-amyloid component effects in human $\mathrm{SH}$ SY5Y cells. ACS Chem Neurosci. 2014; 5:390-9.

Daniele S, Taliani S, Da Pozzo E, Giacomelli C, Costa B, Trincavelli ML, Rossi L, La Pietra V, Barresi E, Carotenuto A, Limatola A, Lamberti A, Marinelli L, Novellino E, Da 
Settimo F, Martini C. Apoptosis therapy in cancer: the first single-molecule coactivating p53 and the translocator protein in glioblastoma. Sci Rep. 2014; 4:4749.

Dörrie J, Sapala K, Zunino S.J. Carnosol-induced apoptosis and downregulation of Bcl-2 in B-lineage leukemia cells. Cancer Lett. 2001; 170:33-9.

England B, Huang T, Karsy M. Current understanding of the role and targeting of tumor suppressor p53 in glioblastoma multiforme. Tumour Biol. 2013; 34:2063-74.

Fabregat I, Roncero C, Fernández M. Survival and apoptosis: a dysregulated balance in liver cancer. Liver Int. 2007; 27:155-62.

Feldser DM, Kostova KK, Winslow MM, Taylor SE, Cashman C, Whittaker CA et al. Stagespecific sensitivity to p53 restoration during lung cancer progression. Nature 2010; 468:572-75.

Fortes C, Forastiere F, Farchi S, Mallone S, Trequattrinni T, Anatra F, Schmid G, Perucci CA. The protective effect of the Mediterranean diet on lung cancer. Nutr Cancer. 2003; 46:30-7.

Green DR, Walczak H. Apoptosis therapy: driving cancers down the road to ruin. Nat Med. 2013; 19:131-3.

Halatsch ME, Schmidt U, Unterberg A, Vougioukas VI. Uniform MDM2 overexpression in a panel of glioblastoma multiforme cell lines with divergent EGFR and p53 expression status. Anticancer Res. 2006; 26:4191-4.

Hemann MT, Lowe SW. The p53-Bcl-2 connection. Cell Death Differ. 2006; 13:1256-9.

Ho IA, Toh HC, Ng WH, Teo YL, Guo CM, Hui KM, Lam PY. Human bone marrow-derived mesenchymal stem cells suppress human glioma growth through inhibition of angiogenesis. Stem Cells. 2013; 31:146-55.

Huang MT, Ho CT, Wang ZY, Ferraro T, Lou YR, Stauber K, Ma W, Georgiadis C, Laskin JD, Conney $\mathrm{AH}$. Inhibition of skin tumorigenesis by rosemary and its constituents carnosol and ursolic acid. Cancer Res. 1994; 54:701-8.

Huang S, Ho C, Lin-Shiau S, Lin J. Carnosol inhibits the invasion of B16/F10 mouse melanoma cells by suppressing metalloproteinase- 9 through downregulating nuclear factor-kappaB and c-Jun. Biochem Pharmacol. 2005; 69:221-32.

Ishii N, Maier D, Merlo A, Tada M, Sawamura Y, Diserens AC, Van Meir EG. Frequent coalterations of TP53, p16/CDKN2A, p14ARF, PTEN tumor suppressor genes in human glioma cell lines. Brain Pathol. 1999; 9:469-79.

Johanson JJ. Carnosol: A promising anti-cancer and inflammatory agent. Cancer Lett. $2011 ; 305: 1-7$. 
Johnson JJ, Mukhtar H. Curcumin for chemoprevention of colon cancer. Cancer Lett. 2007; 255:170-81.

Johnson JJ, Syed DN, Heren CR, Suh Y, Adhami VM, Mukhtar H. Carnosol, a dietary diterpene, displays growth inhibitory effects in human prostate cancer PC3 cells leading to G2-phase cell cycle arrest and targets the 5'-AMP-activated protein kinase (AMPK) pathway. Pharm Res. 2008; 25:2125-34.

Johnson JJ, Syed DN, Suh Y, Heren CR, Saleem M, Siddiqui IA, Mukhtar H. Disruption of androgen and estrogen receptor activity in prostate cancer by a novel dietary diterpene carnosol: implications for chemoprevention. Cancer Prev Res (Phila). 2010; 3:1112-23.

Junttila MR, Karnezis AN, Garcia D, Madriles F, Kortlever RM, Rostker F et al. Selective activation of p53-mediated tumour suppression in high-grade tumours. Nature 2010; 468:567-71.

Khoo KH, Verma CS, Lane DP. Drugging the p53 pathway: understanding the route to clinical efficacy. Nat Rev Drug Discov. 2014 Mar;13(3):217-36.

Khuda-Bukhsh AR, Das S, Saha SK. Molecular Approaches Toward Targeted Cancer Prevention with Some Food Plants and Their Products: Inflammatory and Other Signal Pathways. Nutr Cancer. 2014; 66:194-205.

Kim DH, Kundu JK, Surh YJ. Redox modulation of p53: mechanisms and functional significance. Mol Carcinog. 2011; 50:222-34.

Kim SJ, Kim JS, Cho HS, Lee HJ, Kim SY, Kim S, Lee SY, Chun HS. Carnosol, a component of rosemary (Rosmarinus officinalis L.) protects nigral dopaminergic neuronal cells. Neuroreport. 2006; 17:1729-33.

Kleihues P, Louis DN, Scheithauer BW, Rorke LB, Reifenberger G, Burger PC, Cavenee WK. The WHO classification of tumors of the nervous system. J Neuropathol Exp Neurol. 2002; 61:215-25.

Kondo S, Barnett GH, Hara H, Morimura T, Takeuchi J. MDM2 protein confers the resistance of a human glioblastoma cell line to cisplatin-induced apoptosis. Oncogene. 1995; 10:2001-6.

Kruiswijk F, Labuschagne CF, Vousden KH. p53 in survival, death and metabolic health: a lifeguard with a licence to kill. Nat Rev Mol Cell Biol. 2015; 16:393-405.

Künkele A, De Preter K, Heukamp L, Thor T, Pajtler KW, Hartmann W, Mittelbronn M, Grotzer MA, Deubzer HE, Speleman F, Schramm A, Eggert A, Schulte JH. 
Pharmacological activation of the p53 pathway by nutlin-3 exerts anti-tumoral effects in medulloblastomas. Neuro Oncol. 2012; 14:859-69.

Lo AH, Liang YC, Lin-Shiau SY, Ho CT, Lin JK. Carnosol, an antioxidant in rosemary, suppresses inducible nitric oxide synthase through down-regulating nuclear factorkappaB in mouse macrophages. Carcinogenesis. 2002; 23:983-91.

López-Jiménez A, García-Caballero M, Medina MÁ, Quesada AR. Anti-angiogenic properties of carnosol and carnosic acid, two major dietary compounds from rosemary. Eur J Nutr. 2013; 52:85-95.

Maier T, Güell M, Serrano L. Correlation of mRNA and protein in complex biological samples. FEBS Lett. 2009; 583:3966-73.

Nakamizo A, Marini F, Amano T, Khan A, Studeny M, Gumin J, Chen J, Hentschel S, Vecil G, Dembinski J, Andreeff M, Lang FF. Human bone marrow-derived mesenchymal stem cells in the treatment of gliomas. Cancer Res. 2005 Apr 15;65(8):3307-18. Erratum in: Cancer Res. 2006; 66:5975.

Newman DJ, Cragg GM. Natural products as sources of new drugs over the last 25 years. J Nat Prod. 2007; 70:461-77.

Ngo SN, Williams DB, Head RJ. Rosemary and cancer prevention: preclinical perspectives. Crit Rev Food Sci Nutr. 2011; 51:946-54.

Park KW, Kundu J, Chae IG, Kim DH, Yu MH, Kundu JK, Chun KS. Carnosol induces apoptosis through generation of ROS and inactivation of STAT3 signaling in human colon cancer HCT116 cells. Int J Oncol. 2014; 44:1309-15.

Pérez-Fons L, Garzón MT, Micol V. Relationship between the antioxidant capacity and effect of rosemary (Rosmarinus officinalis L.) polyphenols on membrane phospholipid order. J Agric Food Chem. 2010; 58:161-71.

Poeckel D, Greiner C, Verhoff M, Rau O, Tausch L, Hörnig C, Steinhilber D, SchubertZsilavecz M, Werz O. Carnosic acid and carnosol potently inhibit human 5lipoxygenase and suppress pro-inflammatory responses of stimulated human polymorphonuclear leukocytes. Biochem Pharmacol. 2008; 76:91-7.

Ryu S, Buatti JM, Morris A, Kalkanis SN, Ryken TC, Olson JJ; AANS/CNS Joint Guidelines Committee. The role of radiotherapy in the management of progressive glioblastoma: a systematic review and evidence-based clinical practice guideline. J Neurooncol. 2014; 118:489-99.

Sathornsumetee S, Rich JN, Reardon DA. Diagnosis and treatment of high-grade astrocytoma. Neurol Clin. 2007; 25:1111-39. 
Sato A, Sunayama J, Matsuda K, Seino S, Suzuki K, Watanabe E, Tachibana K, Tomiyama A, Kayama T, Kitanaka C. MEK-ERK signaling dictates DNA-repair gene MGMT expression and temozolomide resistance of stem-like glioblastoma cells via the MDM2-p53 axis. Stem Cells. 2011; 29:1942-51.

Singletary K, MacDonald C, Wallig M. Inhibition by rosemary and carnosol of 7,12dimethylbenz[a]anthracene (DMBA)-induced rat mammary tumorigenesis and in vivo DMBA-DNA adduct formation. Cancer Lett. 1996; 104:43-8.

Stupp R, Mason WP, van den Bent MJ, Weller M, Fisher B, Taphoorn MJ, Belanger K, Brandes AA, Marosi C, Bogdahn U, Curschmann J, Janzer RC, Ludwin SK, Gorlia T, Allgeier A, Lacombe D, Cairncross JG, Eisenhauer E, Mirimanoff RO. Radiotherapy plus concomitant and adjuvant temozolomide for glioblastoma. N Engl J Med. 2005; 352:987-96.

Syed DN, Khan N, Afaq F, Mukhtar H. Chemoprevention of prostate cancer through dietary agents: progress and promise. Cancer Epidemiol Biomarkers Prev. 2007; 16:2193-203.

Tai J, Cheung S, Wu M, Hasman D. Antiproliferation effect of Rosemary (Rosmarinus officinalis) on human ovarian cancer cells in vitro. Phytomedicine 2012; 19:436-43.

Tallarida RJ, Stone DJJR, McCary JD, Raffa RB. Response surface analysis of synergism between morphine and clonidine. J Pharmacol Exp Ther. 1999; 289:8-13.

Tallarida RJ. The interaction index: a measure of drug synergism. Pain 2002; 98:163-168. Taylor WR, Stark GR. Regulation of the G2/M transition by p53. Oncogene. 2001; 20:1803-15.

Torres S, Lorente M, Rodríguez-Fornés F, Hernández-Tiedra S, Salazar M, GarcíaTaboada E, Barcia J, Guzmán M, Velasco G. A combined preclinical therapy of cannabinoids and temozolomide against glioma. Mol Cancer Ther. 2011; 10:90-103.

Uhrinova S, Uhrin D, Powers H, Watt K, Zheleva D, Fischer P, Mclnnes C, Barlow PN. Structure of free MDM2 N-terminal domain reveals conformational adjustments that accompany p53-binding. J Mol Biol. 2005; 350:587-98.

Vergara D, Simeone P, Bettini S, Tinelli A, Valli L, Storelli C, Leo S, Santino A, Maffia M. Antitumor activity of the dietary diterpene carnosol against a panel of human cancer cell lines. Food Funct. 2014; 5:1261-9.

Villalonga-Planells R, Coll-Mulet L, Martínez-Soler F, Castaño E, Acebes JJ, GiménezBonafé P, Gil J, Tortosa A. Activation of p53 by nutlin-3a induces apoptosis and 
cellular senescence in human glioblastoma multiforme. PLoS One. 2011 Apr 5;6(4):e18588.

Visanji JM, Thompson DG, Padfield PJ. Induction of G2/M phase cell cycle arrest by carnosol and carnosic acid is associated with alteration of cyclin A and cyclin B1 levels. Cancer Lett. 2006; 237:130-6.

Wagner J, Ma L, Rice JJ, Hu W, Levine AJ, Stolovitzky GA. p53-Mdm2 loop controlled by a balance of its feedback strength and effective dampening using ATM and delayed feedback. Syst Biol (Stevenage). 2005; 152:109-18.

Wang CC, Liao YP, Mischel PS, Iwamoto KS, Cacalano NA, McBride WH. HDJ-2 as a target for radiosensitization of glioblastoma multiforme cells by the farnesyltransferase inhibitor R115777 and the role of the p53/p21 pathway. Cancer Res. 2006; 66:675662.

Weckesser S, Engel K, Simon-Haarhaus B, Wittmer A, Pelz K, Schempp CM. Screening of plant extracts for antimicrobial activity against bacteria and yeasts with dermatological relevance. Phytomedicine. 2007; 14:508-16.

Xue W, Zender L, Miething C, Dickins RA, Hernando E, Krizhanovsky V et al. Senescence and tumour clearance is triggered by p53 restoration in murine liver carcinomas. Nature 2007; 445:656-60.

Zimmermann GR, Lehár J, Keith CT. Multi-target therapeutics: when the whole is greater than the sum of the parts. Drug Discov Today. 2007; 12:34-42. 


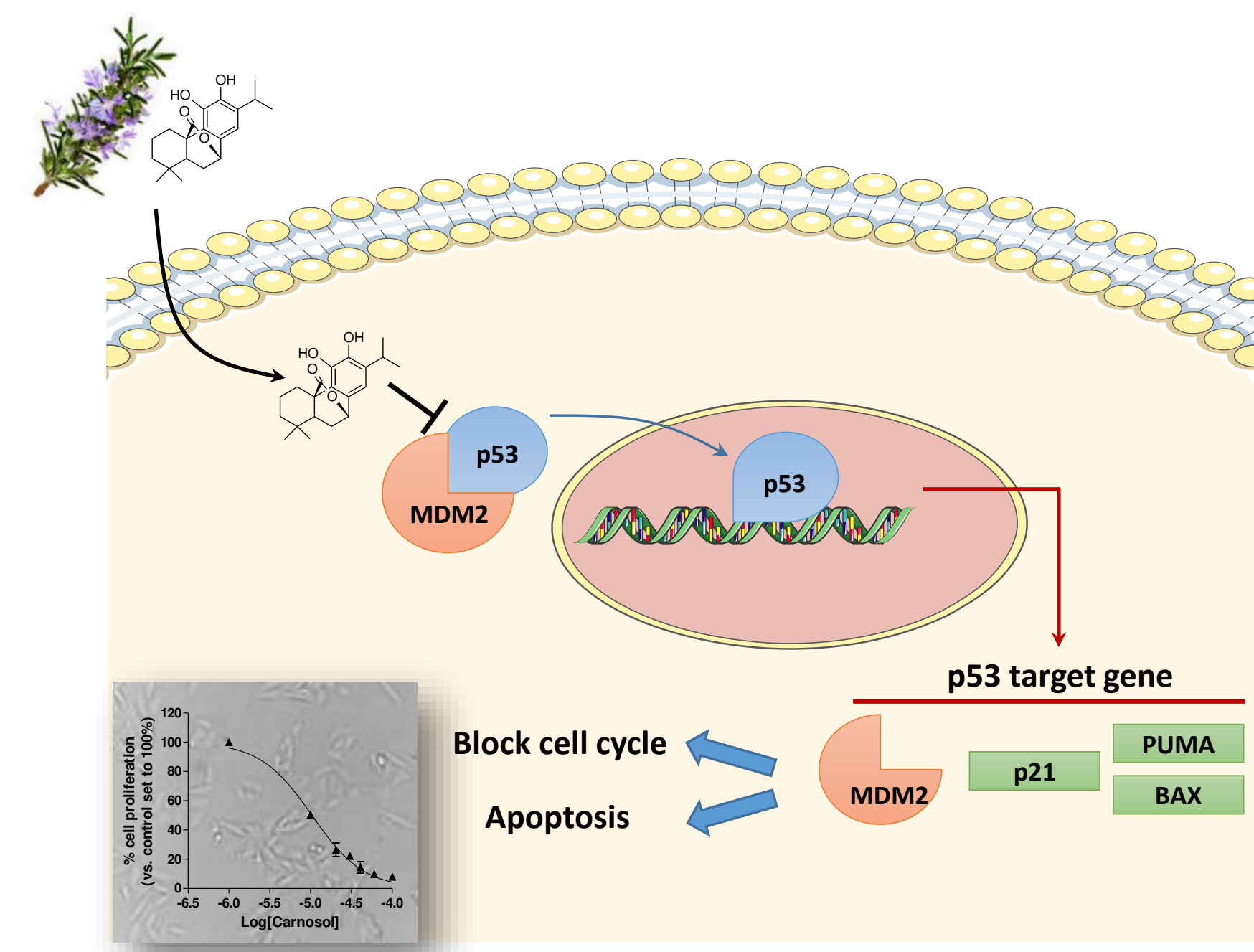


A

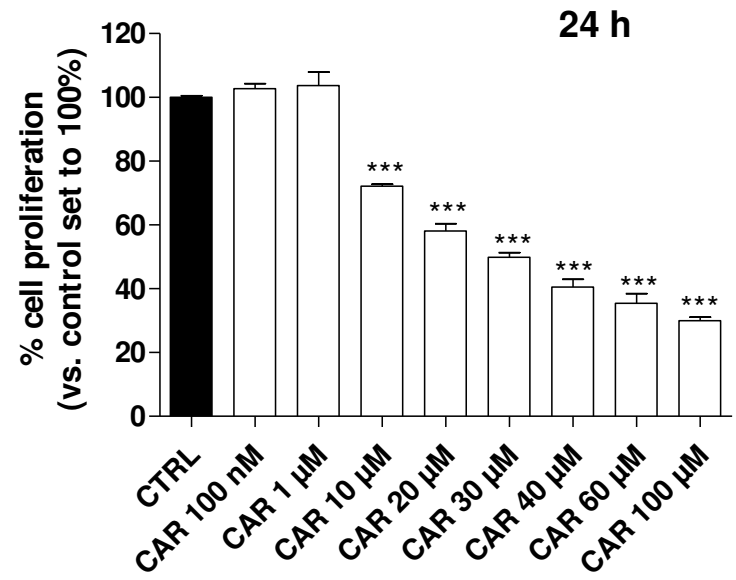

C

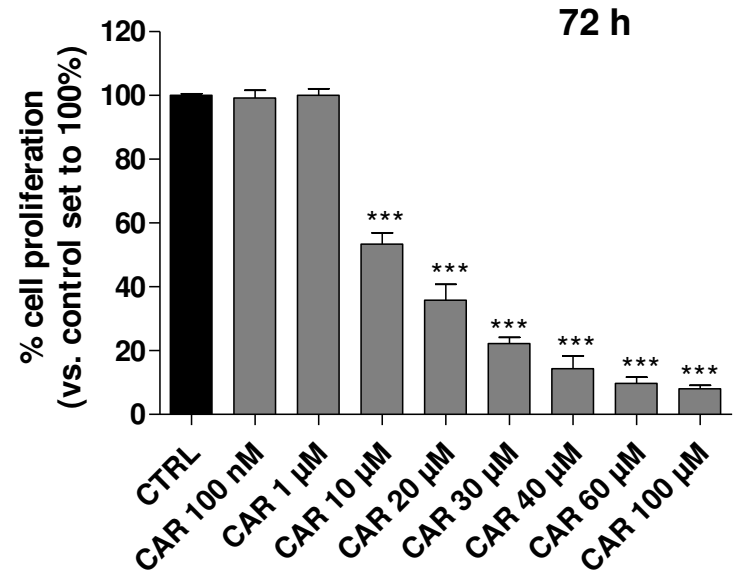

B
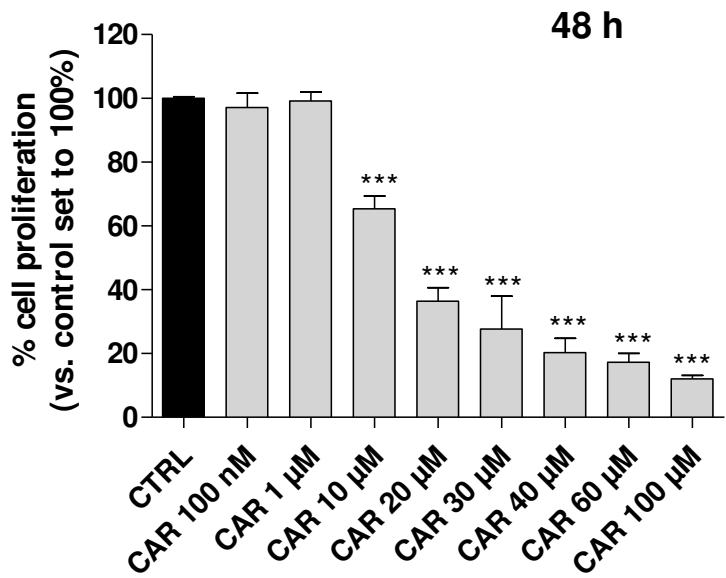

D

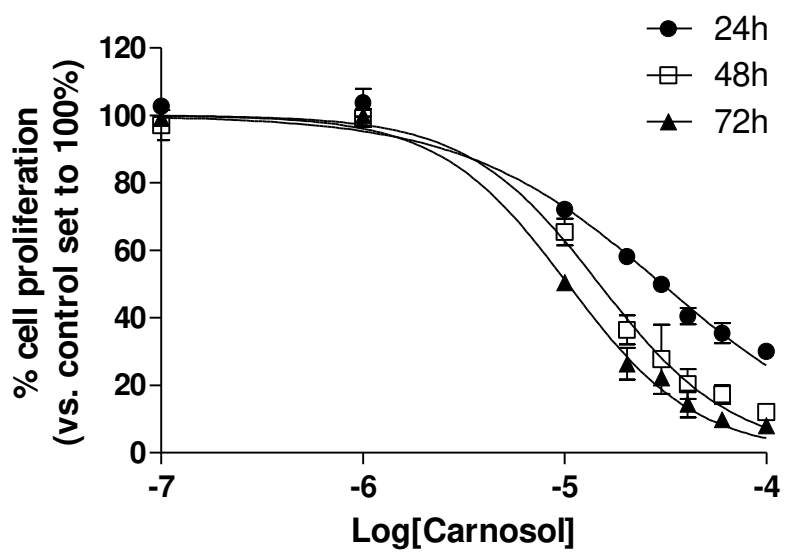

E
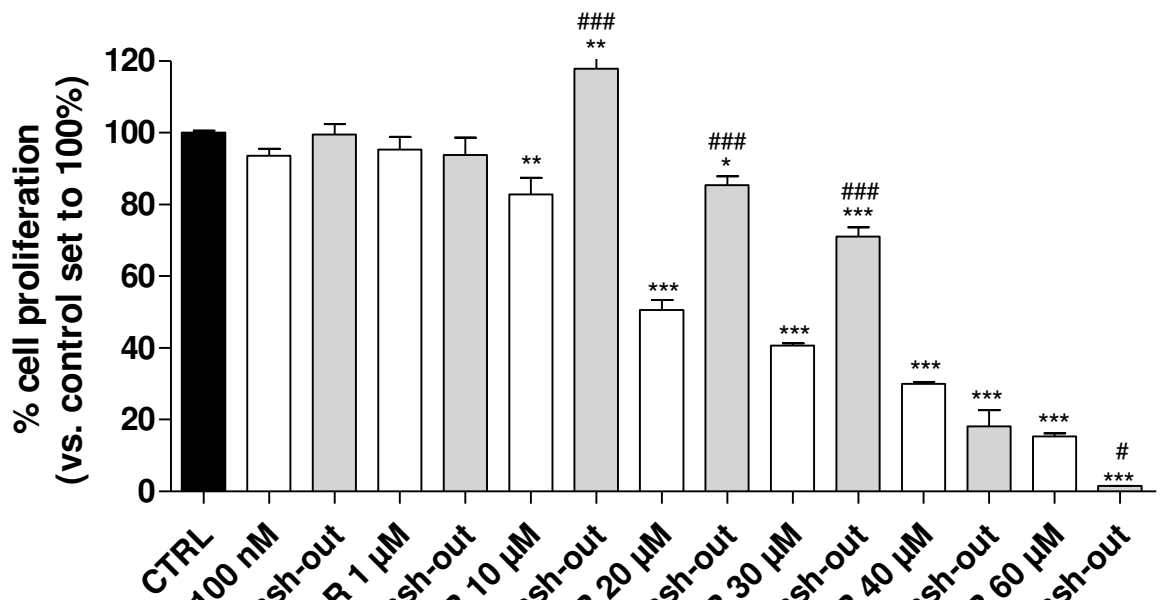

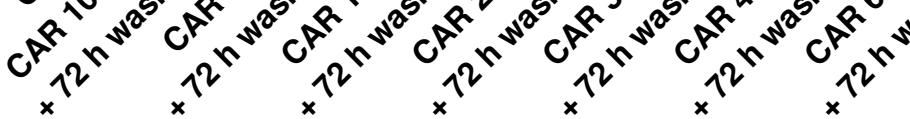


A

U343MG

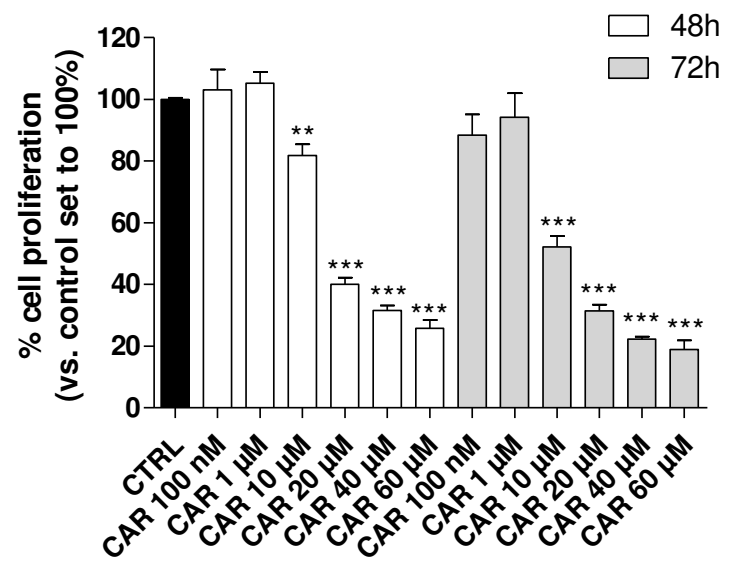

C

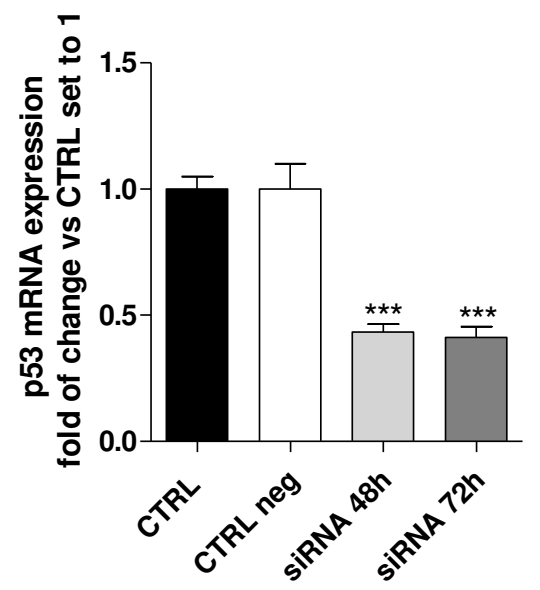

E

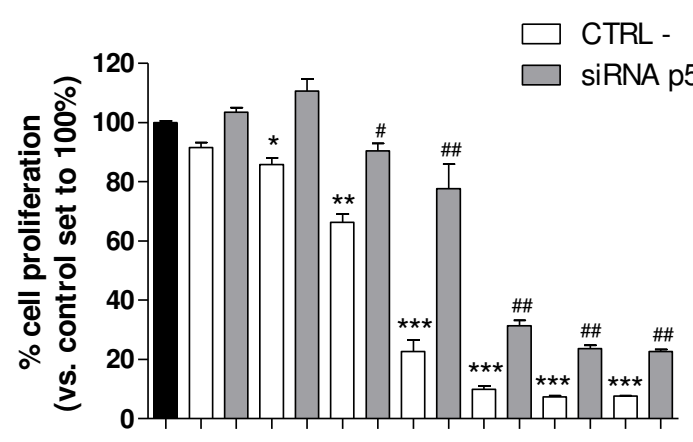

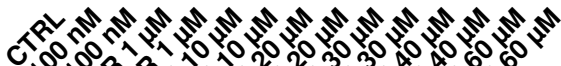

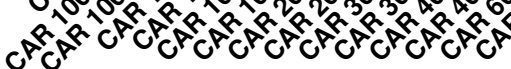

B

T98G

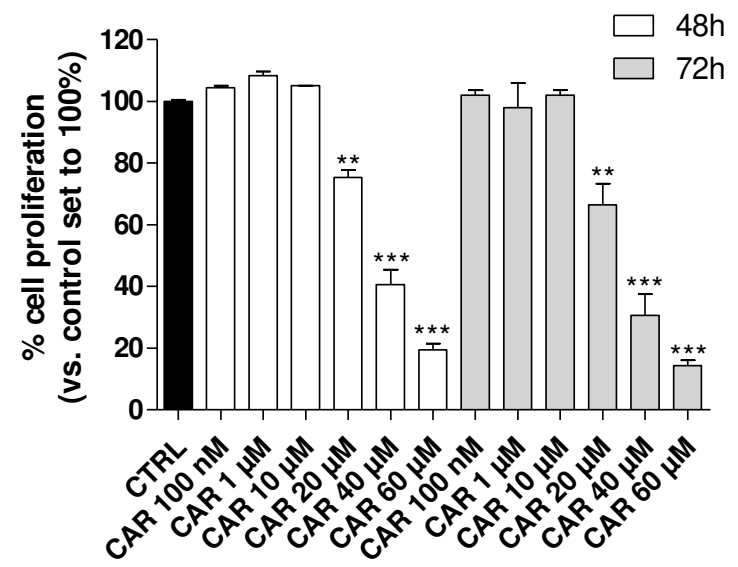

D

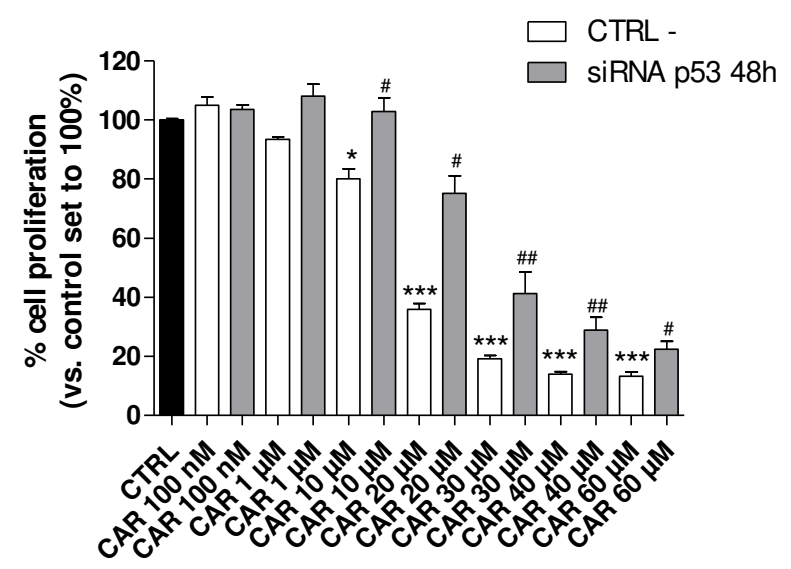



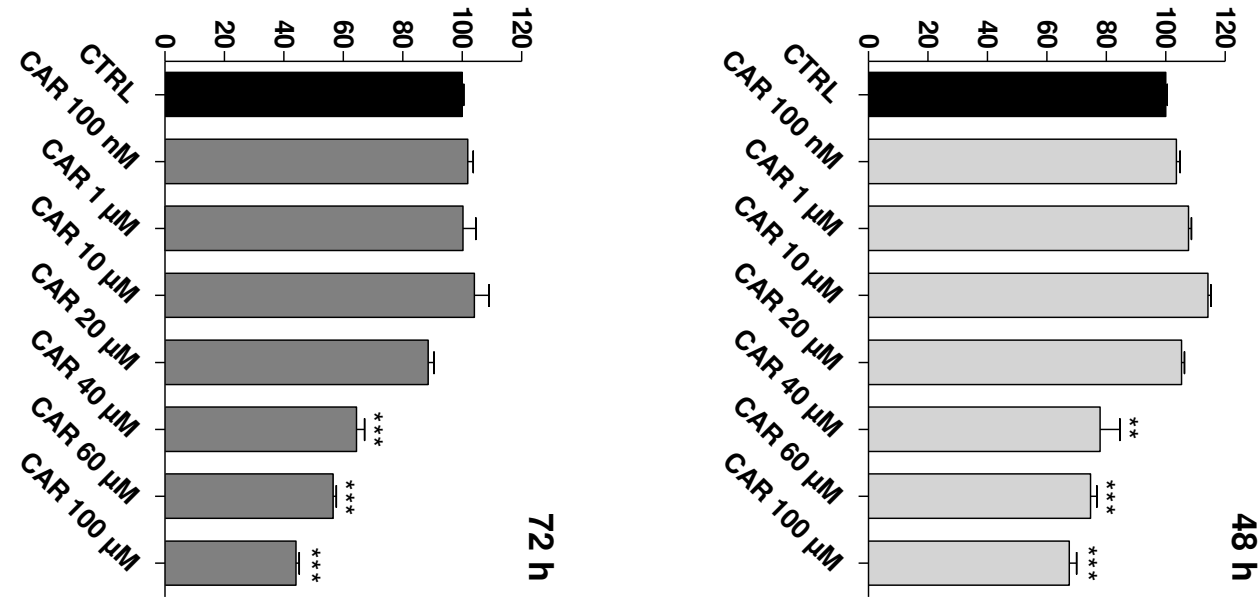

$\%$ cell proliferation (vs. control set to $100 \%$ )

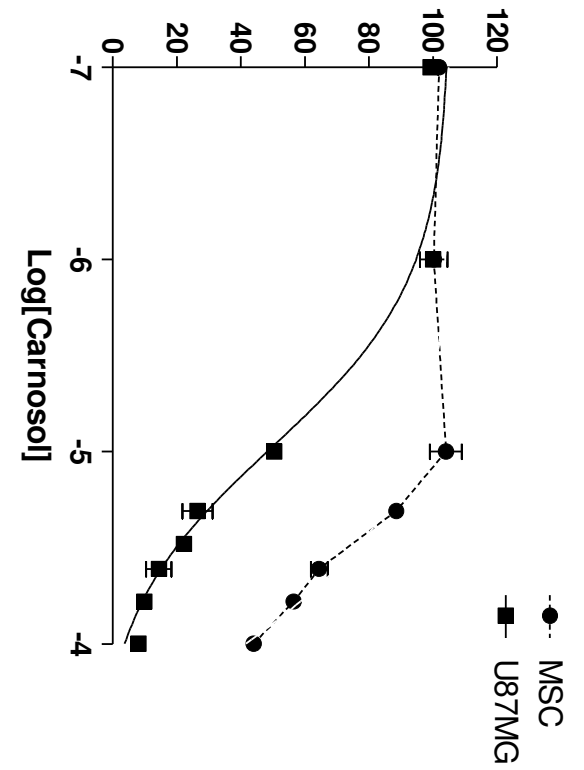

$\%$ cell proliferation

$\boldsymbol{\infty}$ (vs. control set to $100 \%$ )

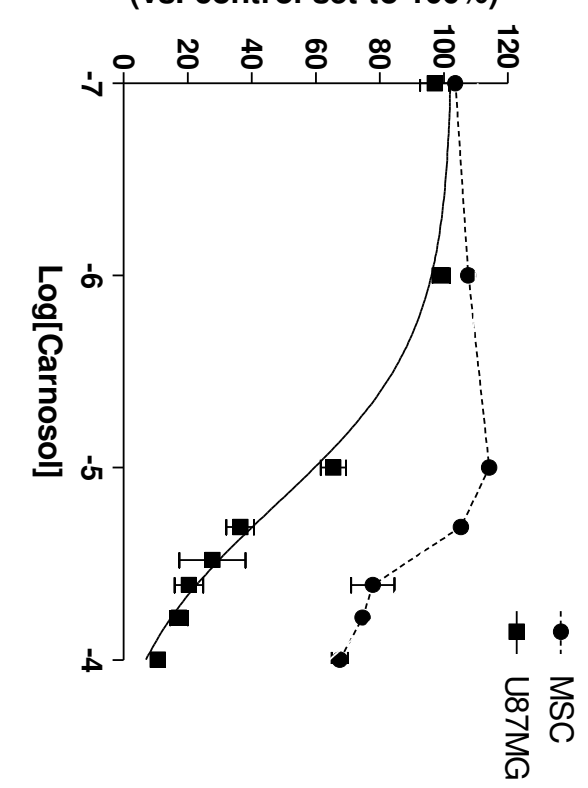



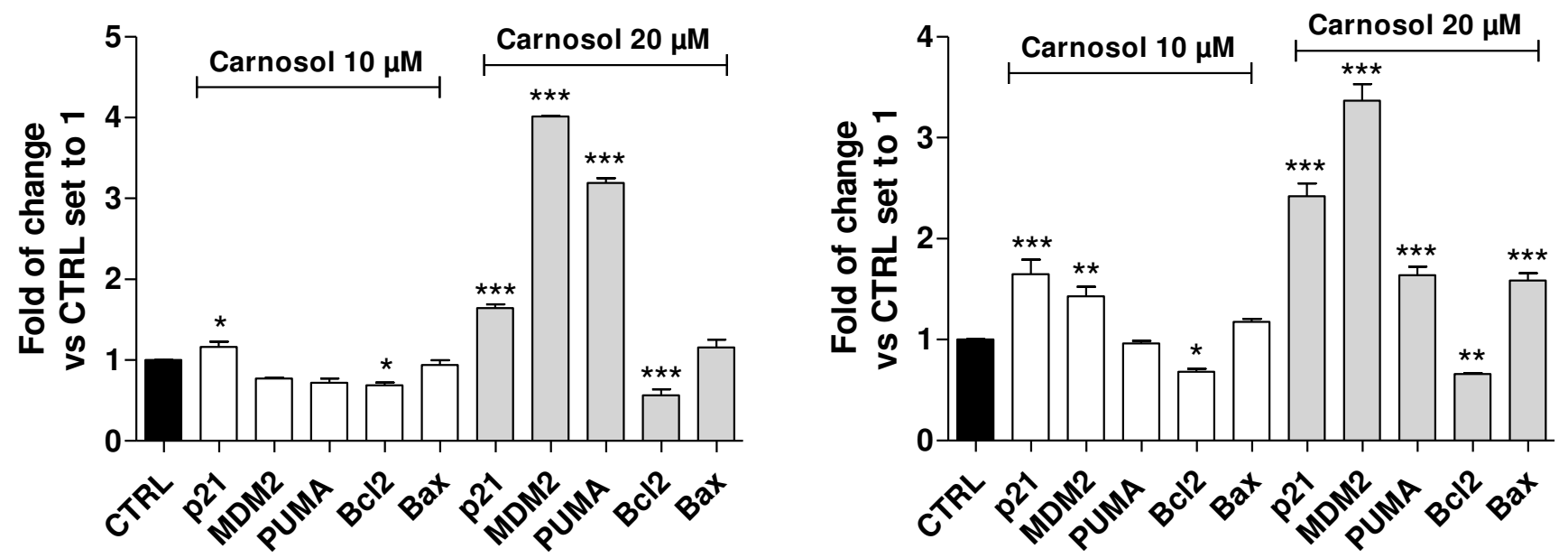

C

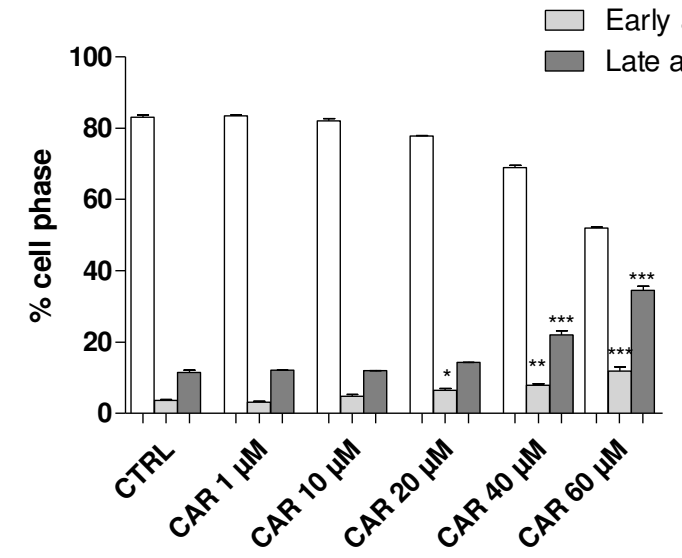

E

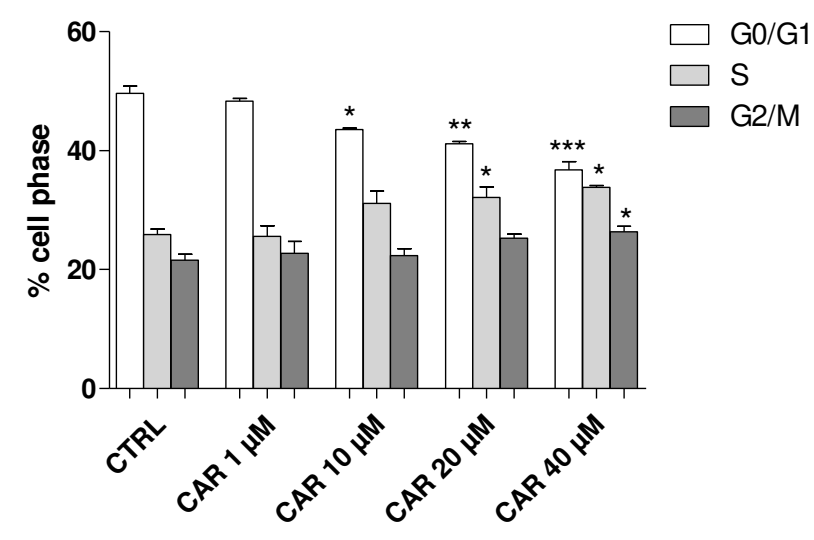

D

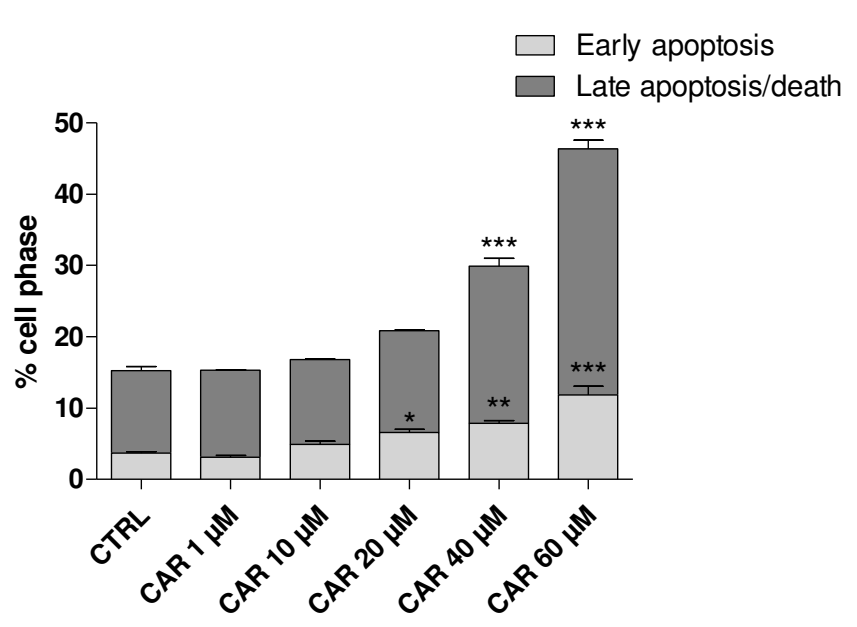




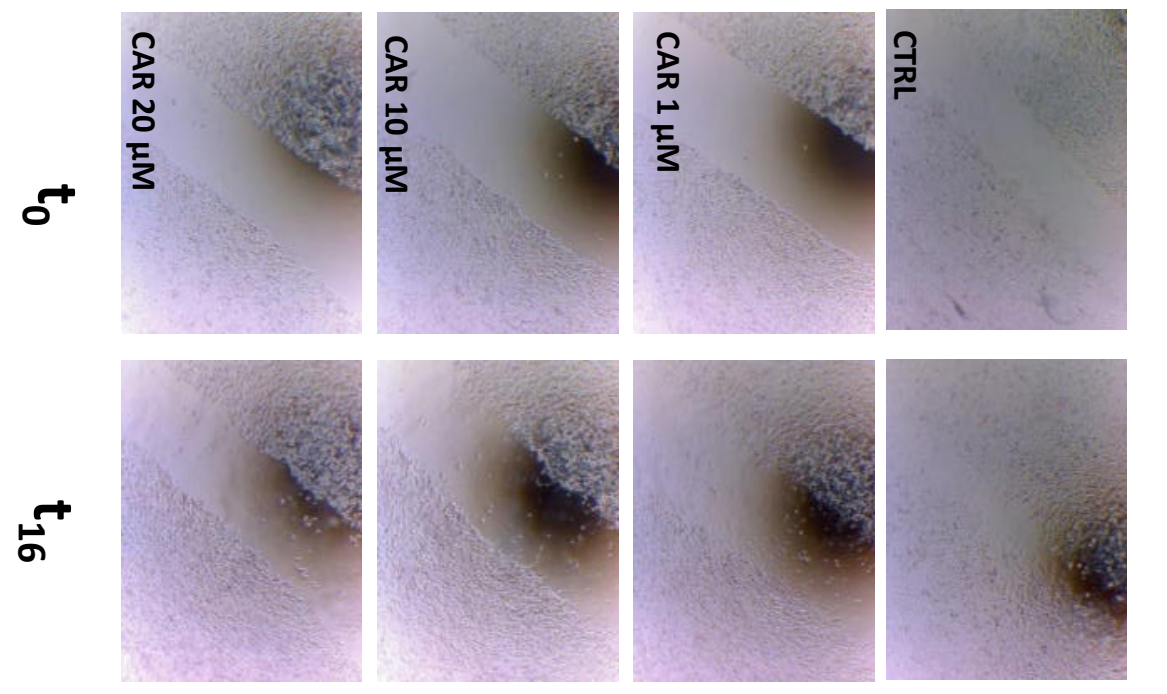

n

$\boldsymbol{0}$

$\%$ cell migration (vs $t_{0}$ )
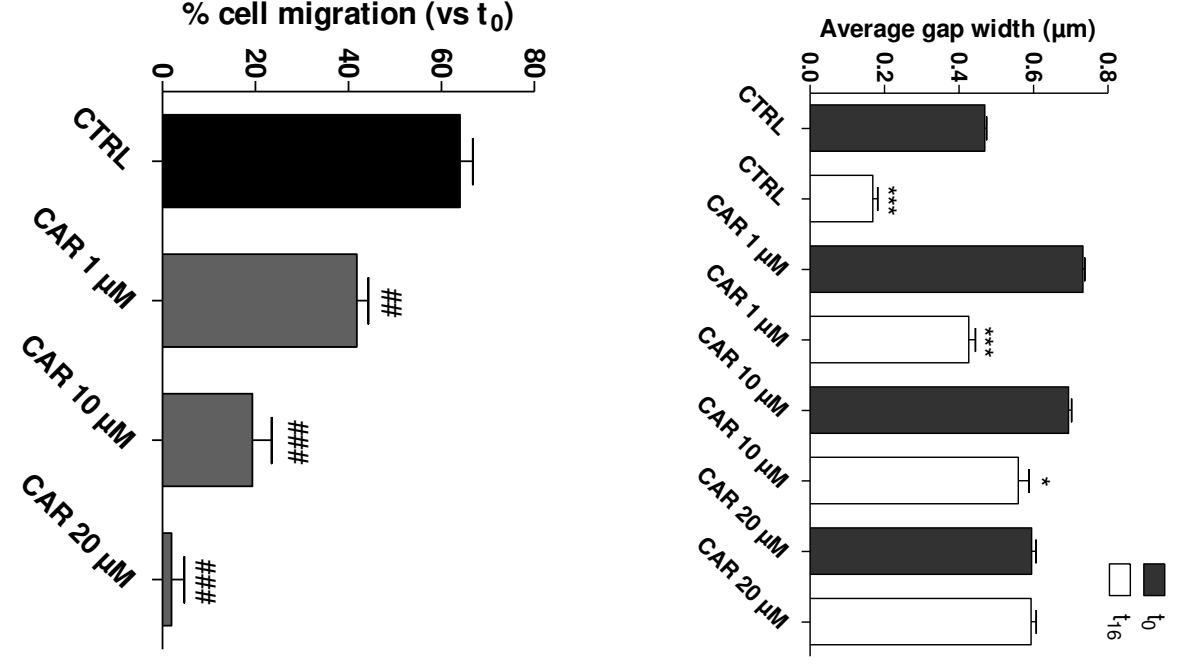
$\%$ cell proliferation (vs. control set to $100 \%$ )

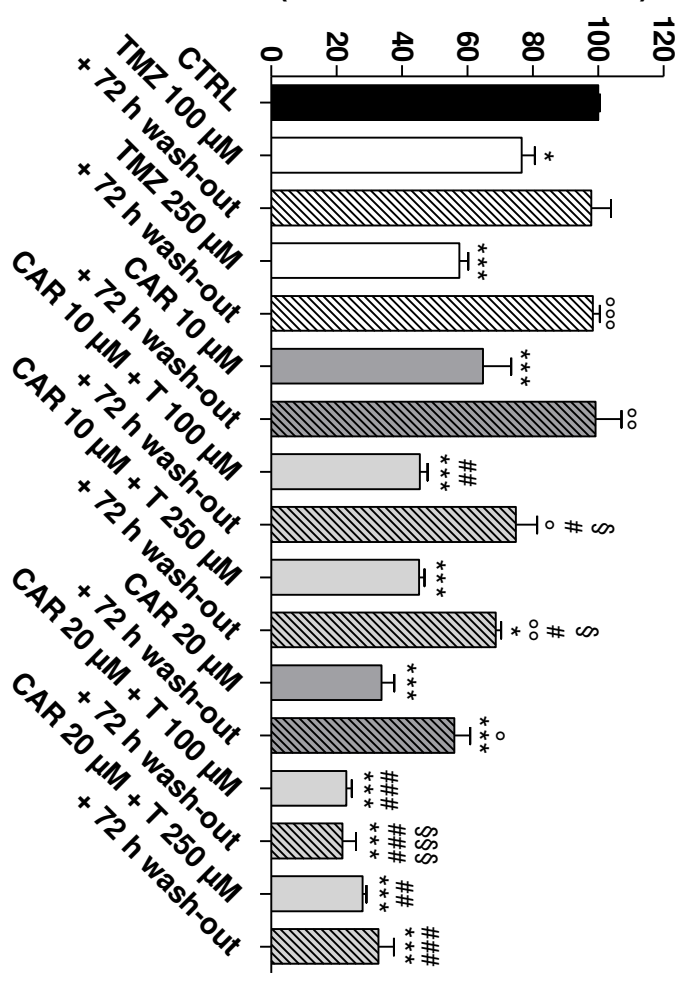

$\Omega$

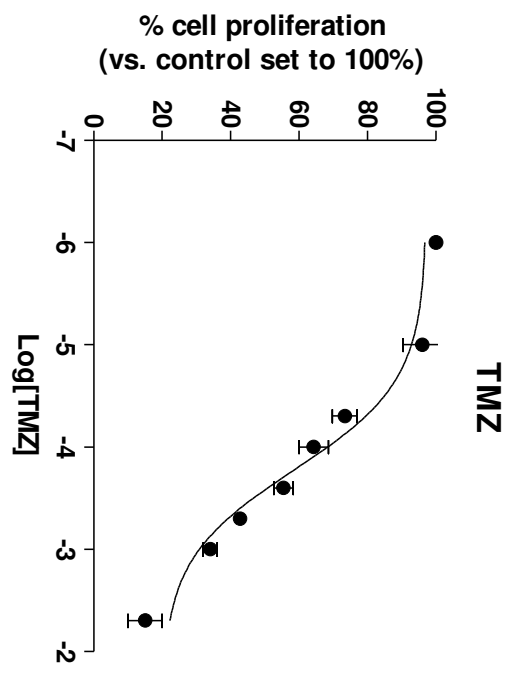

$\boldsymbol{\infty}$

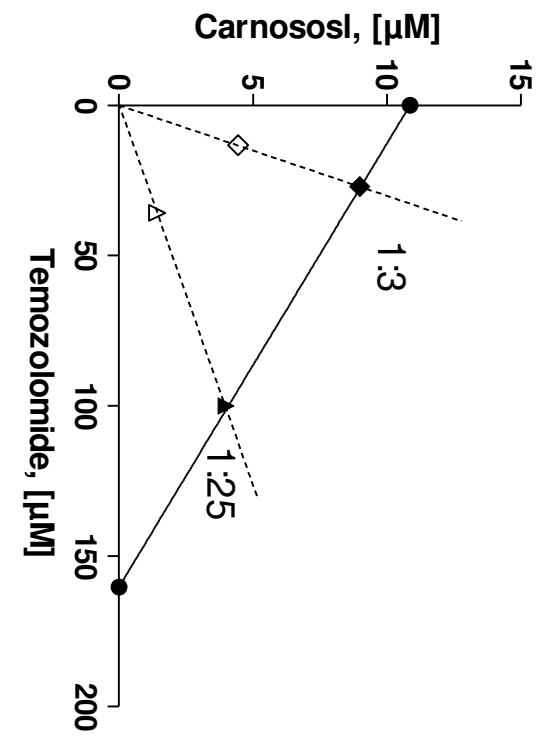


A

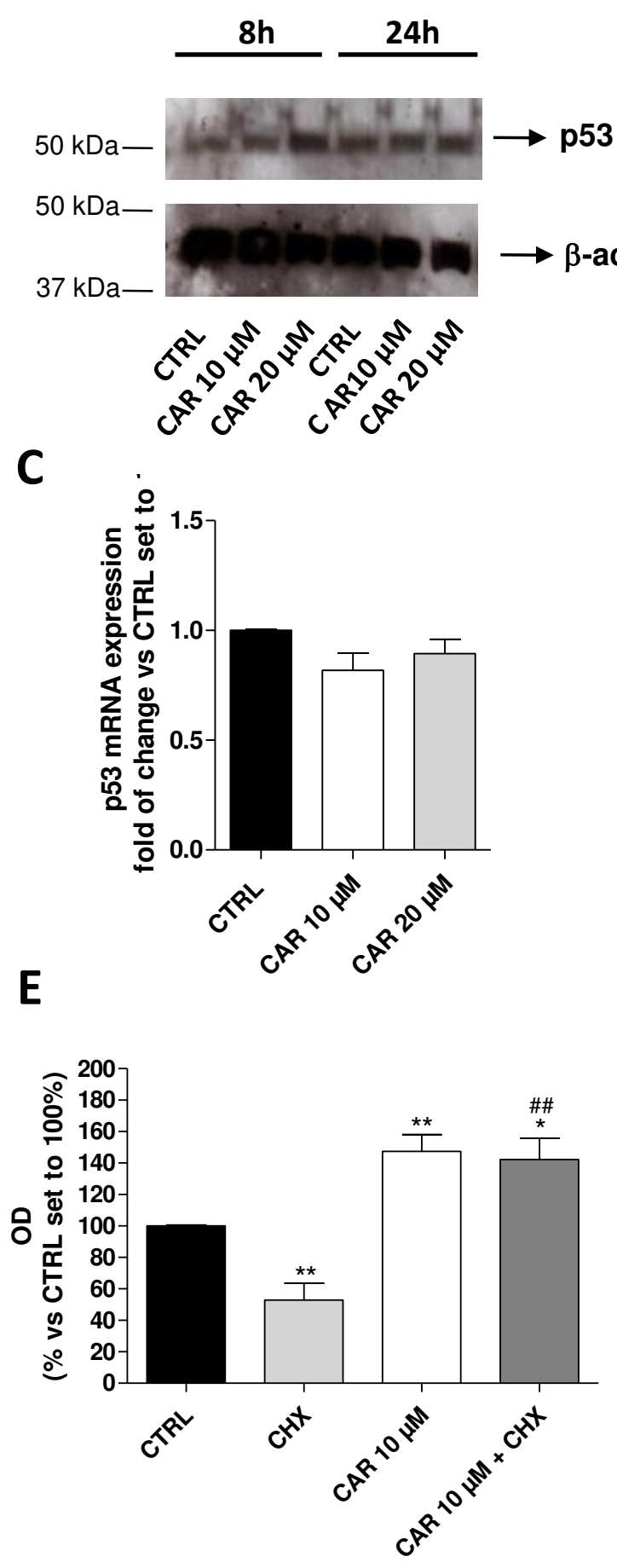

G

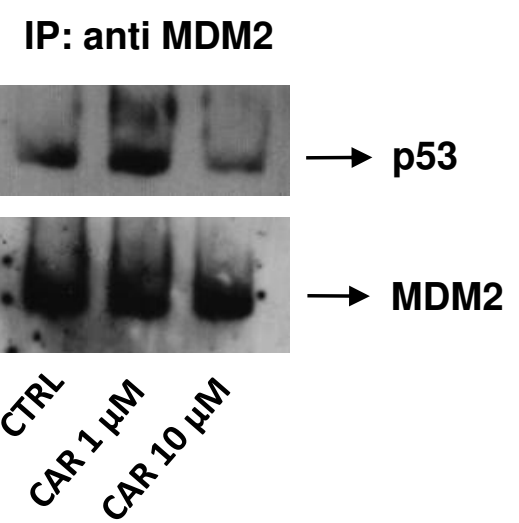

B
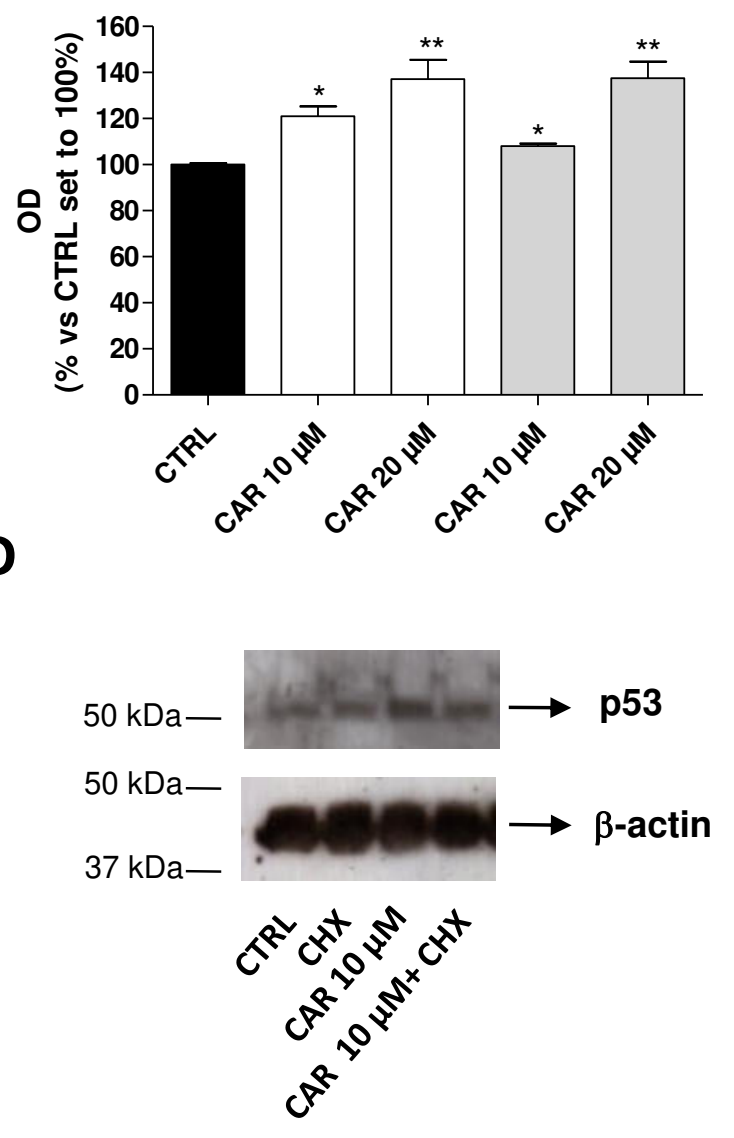

F

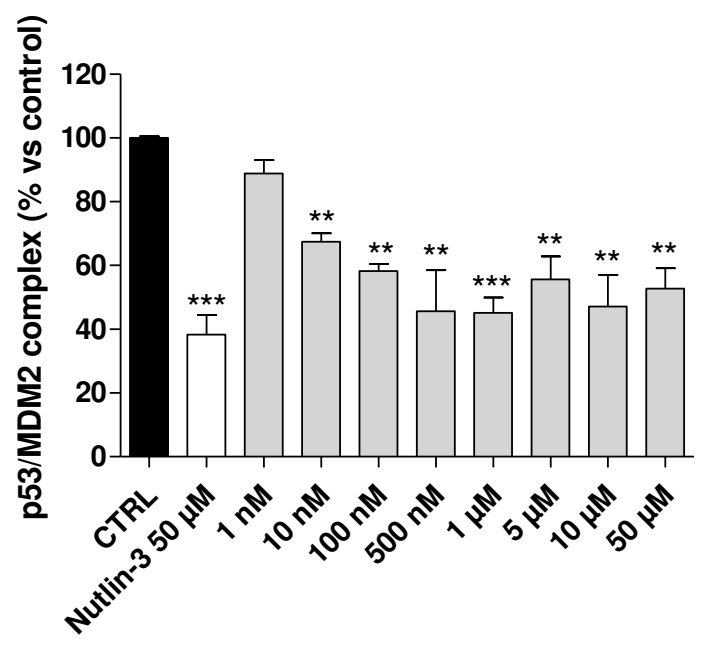

H

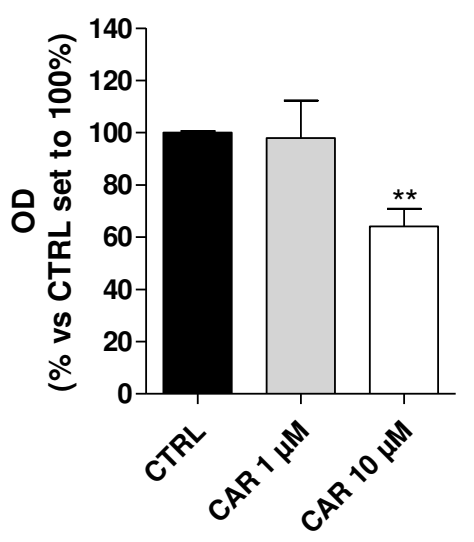




\begin{tabular}{|c|c|c|}
\hline Gene & Primer nucleotide sequences & $\begin{array}{l}\text { Product size } \\
\text { (base pairs) }\end{array}$ \\
\hline MDM2 & $\begin{array}{l}\text { FOR: 5'-TCTAGGAGATTTGTTTGGCGT-3' } \\
\text { REV: 5'-TCACAGATGTACCTGAGTCC-3' }\end{array}$ & $125 \mathrm{bp}$ \\
\hline p21 & $\begin{array}{l}\text { FOR: 5'-TGCCGAAGTCAGTTCCTTG -3' } \\
\text { REV: 5'-CATGGGTTCTGACGGACATC-3' }\end{array}$ & $134 \mathrm{bp}$ \\
\hline BAX & $\begin{array}{l}\text { FOR: 5'-TTTGCTTCAGGGTTTCATCC-3' } \\
\text { REV: 5'-CAGTTGAAGTTGCCGTCAGA-3' }\end{array}$ & $245 \mathrm{bp}$ \\
\hline PUMA & $\begin{array}{l}\text { FOR: 5'-GAGGAGGAACAGTGGGC-3' } \\
\text { REV: 5'- CTAATTGGGCTCCATCTCGG-3' }\end{array}$ & $198 \mathrm{bp}$ \\
\hline p53 & $\begin{array}{l}\text { FOR: 5'-CTTTGAGGTGCGTGTTTGTG-3' } \\
\text { REV: 5'-GTGGTTTCTTCTTTGGCTGG-3' }\end{array}$ & $161 \mathrm{bp}$ \\
\hline $\mathrm{Bcl}-2$ & $\begin{array}{l}\text { FOR: 5'-GAGGATTGTGGCCTTCTTTG-3' } \\
\text { REV: 5'-ACAGTTCCACAAAGGCATCC-3' }\end{array}$ & $171 \mathrm{bp}$ \\
\hline NF-kB & $\begin{array}{l}\text { FOR: 5'-GCTCCGGAGACCCCTTCCA-3' } \\
\text { REV: 5'-GGTTTGAGGTAGTTTCCCAGT-3' }\end{array}$ & $198 \mathrm{bp}$ \\
\hline$\beta$-actin & $\begin{array}{c}\text { FOR: 5'-GCACTCTTCCAGCCTTCCTTCC-3' } \\
\text { REV: 5'-GAGCCGCCGATCCACACG-3' }\end{array}$ & $254 \mathrm{bp}$ \\
\hline
\end{tabular}

Table 1. Primers Used for Real-Time RT-PCR. 


\begin{tabular}{cccc}
\hline $\begin{array}{c}\text { CAR/TMZ } \\
\text { ratio }\end{array}$ & $\mathrm{IC}_{50, \text { mix }}(\mu \mathrm{M})$ & $\begin{array}{c}\mathrm{IC}_{50, \text { add }}(\mu \mathrm{M}) \\
\text { calculated }\end{array}$ & $\mathrm{Y}$ \\
\hline CAR & $10.4 \pm 0.5$ & - & - \\
\hline TMZ & $160.4 \pm 12.4$ & - & - \\
\hline $\mathbf{1 : 3}$ & $21.0 \pm 3.5^{\star}$ & 36.2 & 0.9 \\
\hline $\mathbf{1 : 2 5}$ & $50.6 \pm 5.4^{\star \star \star}$ & 105.1 & 0.7 \\
\hline
\end{tabular}

Table 2. Isobolographic analysis of CAR and TMZ in U87MG. Data are presented as IC 50 \pm S.E.M. Statistical analysis was performed with Student's $t$-test. ${ }^{*} P \leq 0.05$, ${ }^{* * *} P \leq 0.001$ vs the respective additive group. $\mathrm{Y}<1$ indicates supra-additivity (synergy). 